\title{
Beatus manuscripts under the microscope: the Alcobaça Beatus and the Iberian Cistercian tradition revisited
}

\author{
Alicia Miguélez Cavero ${ }^{\mathrm{a}}\left(\right.$ ) $^{2}$ Maria João Melo ${ }^{\mathrm{a}, \mathrm{b}, \mathrm{c}}$, Maria Adelaide Miranda ${ }^{\mathrm{a}}$, Rita Castro ${ }^{\mathrm{a}}$ \\ $\mathrm{b}, \mathrm{c}$ and Conceição Casanova ${ }^{\mathrm{b}, \mathrm{d}}$
}

a IEM Instituto de Estudos Medievais, Faculty of Social Sciences and Humanities, Universidade NOVA de Lisboa,

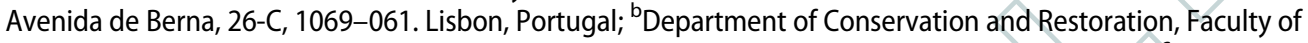
Sciences and Technology, Universidade NOVA de Lisboa, 2829-516 Monte da Caparica, Portugal; 'REQUIMTE, LAQV, Faculty of Sciences and Technology, Universidade NOVA de Lisboa, 2829-516 Monte da Caparica, Portugal; ${ }^{\mathrm{d}}$ Museus da Universidade de Lisboa (ULisboa), Rua da Escola Politécnica 56/58, 1250-102 Lisbon, Portugal

\section{ABSTRACT}

The Alcobaça Beatus (Lisbon, National Library, Alc. 247) is one of the few extant unillustrated copies of the eighth-century Commentary on the Apocalypse attributed to the Iberian monk Beatus of Liébana. It has traditionally been considered that this Beatus was produced at the Cistercian Portuguese abbey of Santa Maria de Alcobaça and that its model was the Lorvão Beatus (Lisbon, Arquivo Nacional da Torre do Tombo, Ordem de Cister, Mosteiro de Santa Maria de Lorvão, Liv. 44). This article provides the first indepth examination of the Alcobaça Beatus, carried out by a multidisciplinary team using combined methods from the natural and human sciences. The technical data provided by the analysis of the decoration, molecular palette and bookbinding support the theory of its production at the scriptorium of the Portuguese monastery of Alcobaça, whereas the analysis of the textual structure and content reveals that the Alcobaça Beatus and the Lorvão Beatus show a different sequence of texts and that the Alcobaça copy contains later notes that evidence its use in the monastic reading practice, especially the liturgical readings of the Divine Office. This set of results turns this manuscript, which had received minimal scholarly attention to date, into a significant case study since it reveals itself as the basis to further investigate the corpus of extant Beatus copies and question the importance of such a work within the Cistercian order, thus provoking new questions within the debate on Cistercians and their identity around the year 1200 .

\section{ARTICLE HISTORY}

Received 1 March 2016

Accepted 2 August 2016

\section{KEYWORDS}

Cistercians; Beatus

manuscripts; Alcobaça abbey; medieval colours; colour construction; conservation of cultural heritage

\section{Introduction}

This paper provides the first in-depth study of the so-called "Alcobaça Beatus", ${ }^{1}$ one of the medieval copies of the Commentary on the Apocalypse by the monk Beatus of Liébana,

CONTACT Alicia Miguélez Cavero amiguelez@fcsh.unl.pt

${ }^{1}$ Lisbon, Biblioteca Nacional, Ms. Alc. 247. The manuscript can be accessed in full on the Biblioteca Nacional de Portugal site: http://purl.pt/23886.

(c) 2016 Informa UK Limited, trading as Taylor \& Francis Group 
who lived in eighth-century northern Iberia. ${ }^{2}$ The original work does not survive, but it was recopied multiple times between the ninth and sixteenth centuries. The remaining manuscripts constitute three families: Branch I, the closest to the archetype; and Branch II, which is divisible into two sub-branches: IIa and IIb. ${ }^{3}$

The copy that is examined here, which received minimal scholarly attention prior to this article, ${ }^{4}$ has traditionally been ascribed to the scriptorium of the monastery of Alcobaça, and its model was taken to be the Lorvão Beatus. The Lorvão Beatus is an illuminated commentary that was produced in 1189 at the monastery of São Mamede of Lorvão. ${ }^{5}$ Here we undertake a study that combines methods from the natural and human sciences, which are used to confirm whether the manuscript was actually produced in Alcobaça and whether it copied the Lorvão Beatus.

This study was carried out by an interdisciplinary team - comprising two art historians, one chemist, and two specialists in conservation and restoration - familiar with the Cistercian tradition, Beatus manuscripts, and the characterisation of the colour paints used in Portuguese monastic manuscripts from twelfth- and thirteenth-century Portugal. The team analysed the manuscript's textual structure, decoration and colour, identified chemical composition of the pigments, and studied its bookbinding, in order to determine whether the results are consistent with those of Portuguese manuscripts from the turn of the thirteenth century in general and, more specifically, of those known to have been produced in the Alcobaça scriptorium. ${ }^{6}$ The results of our analysis form the basis for using the Alcobaça Beatus as a case study to advance the state of knowledge on several issues concerning Beatus manuscripts, Cistercian tradition and the monastery of Alcobaça itself.

The Portuguese monastery of Alcobaça (Mosteiro de Santa Maria de Alcobaça) was founded as the fifty-third affiliate of Clairvaux and was favoured by the recently installed monarchy of Afonso Henriques (r. 1139-1185). ${ }^{7}$ In 1153, the king granted the "Carta de Couto" - a donation of lands exempted from royal taxes - directly to Bernard of Clairvaux, awarding to the Cistercian Order a territory of about 44,000 hectares in an extremely fertile valley at the confluence of two rivers and near the coast. ${ }^{8}$ For the Cistercians, the establishment of this vast domain definitively helped to consolidate their position in the Iberian Peninsula, along with the houses of Santes Creus and Poblet in Catalonia, Las Huelgas in Castile and Carracedo in León.

\footnotetext{
${ }^{2}$ The most recent consideration of the Beatus Commentary's authorship was carried out by Roger Gryson in his edition of the text; he concluded that there is no reason to doubt that Beatus was the author. See Beati Liebanensis, vol. 1, xi-xiii. ${ }^{3}$ Klein, Der ältere Beatus-Kodex, 170-217; Williams, The Illustrated Beatus, vol. 1, 19-30; Beati Liebanensis, vol. 1, xxx-lviii. ${ }^{4}$ Los Beatos. Europalia 98 España, 108, n. 9; Díaz y Díaz, Index Scriptorum Latinorum, vol. 1, 110, n. 412; Inventário dos Códices Alcobacenses, 217-8; Inventário dos códices iluminados, 169; Klein, Beato de Liébana, 43, 47; Mundó, "Sobre los códices de Beato", 112; Mundó and Sánchez Mariana, El Comentario de Beato, 28, n. 8; Millares Carlo, "Problemas que suscita la escritura", 209.

${ }^{5}$ Lisbon, Arquivo Nacional da Torre do Tombo, Ordem de Cister, Mosteiro de Santa Maria de Lorvão, Liv. 44 (http://digitarq. arquivos.pt/details?id=4381091). The Lorvão Beatus is commonly known in the Portuguese historiography as the Apocalipse do Lorvão since it was brought to the Portuguese National Archive by the historian Alexandre Herculano, who had received it directly from the Lorvão Cistercian community in 1853. It is a manuscript of $357 \times 259 \mathrm{~mm}$ and it comprises 219 folios, arranged in twenty-eight quires of four bifolia. The text is divided into two columns of twenty-nine lines.

${ }^{6}$ Melo, Castro and Miranda, "Colour: between Beauty and Meaning"; Muralha, Miguel and João Melo, "Micro-Raman study of Medieval Cistercian manuscripts".

${ }^{7}$ Gomes, "Revisitação a um velho tema", 27-72; Marques, Estudos sobre a Ordem de Cister, 354; Marques, "A Introdução da Ordem de Cister em Portugal", 165-93.

${ }^{8}$ Rodrigues, Mosteiro de Alcobaça, 11.
} 
Construction of the new monastery began only in 1178 and ended circa $1252 .{ }^{9}$ The library of this abbey is believed to have been one of the richest in the Cistercian order and to have had the most important collection of illuminated manuscripts from medieval Portugal. ${ }^{10}$ Alcobaça offers a significant case study for the current historiographical debate on the centralistic Cistercian order and its distribution and conformity on the one hand, and the adoption or appropriation of regional elements on the other - an issue which has been intensively discussed in studies focusing on Cistercian architecture, liturgy and book production. ${ }^{11}$

From the very beginning, in the scriptorium of Alcobaça, artistic and textual traditions from Iberia and central France converged, as Aires Nascimento has underscored. ${ }^{12}$ This 100 convergence occurred in works coming from Clairvaux and other French Cistercian monasteries, which exemplify the influence of Burgundy on the liturgy and the scriptorium since its founding. However, regional influence is also attested, since the library featured works not linked to the liturgy of the White Monks, but to Iberian traditions. This applies to its copy of Gregory the Great's Moralia in Job (MS Alc. 349), with an introduction drawn from Isidore of Seville's De viris illustribus and the Continuatio Hispana (Mozarabic Chronicle of 754); ${ }^{13}$ a Marial presenting analogies with the Milagros de Nuestra Señora (Miracles of Our Lady) by Gonzalo de Berceo (MS Alc. 149); $;^{14}$ two copies of the Vitae patrum by Valerius of Bierzo (MSS Alc. 367 and 454), and a copy of the Liber Sancti Iacobi (MS Alc. 334). ${ }^{15}$ Moreover, several scholars have noted the exchanges and loans between Alcobaça and other Cistercian 110 houses of the Iberian Peninsula, especially Las Huelgas in Burgos. The practice of loans was also carried out by other Portuguese monasteries such as Arouca, which received manuscripts from the Galician house of Santa María de Montederramo and the Castilian community of Santa María de la Santa Espina. ${ }^{16}$

Bearing this context in mind, the Alcobaça Beatus reveals as an interesting case because we can question whether the existence of a Beatus in this Cistercian abbey should be credited to Iberian tradition, to Cistercian interest in the Beatus Commentary, to an established Beatus tradition in the Portuguese territory, or to some characteristic of the community of Alcobaça itself. Of particular interest is the fact that the Alcobaça Beatus is traditionally dated to the late twelfth or early thirteenth centuries, ${ }^{17}$ a period that witnessed a flourishing of Beatus manuscripts in northern Iberia.

Overall, Beatus manuscripts are known for their illuminations and the close connection between texts and images, in this sense comparable to other medieval works such as the Psychomachia or the Speculum Virginum. ${ }^{18}$ However, the Alcobaça codex is one of the

${ }^{9}$ Gusmão, A Real Abadia de Alcobaça.

${ }^{10}$ Nascimento, "A experiência do livro", 121-45; Miranda, "Iluminura românica em Portugal", 379.

${ }^{11}$ Bondéelle, "Trésor des moines", 72; Oliver, Singing with Angels; Ó Riain, "The Magnum Legendarium Austriacum"; Untermann, Forma ordinis.

${ }^{12}$ Nascimento, "Le scriptorium d'Alcobaça", 159.

${ }^{13}$ Nascimento, "Um testemunho da tradição hispânica", 313-31.

${ }^{14}$ Nascimento, "Um Marial Alcobacense", 339-412; idem, "Le scriptorium d'Alcobaça", 157.

${ }^{15}$ Díaz y Díaz, Valerio del Bierzo, 139-40; Machado, "Memory, Identity", 135-64.

${ }^{16}$ Galván Freile, "El proceso de internacionalización", 437-56; Suárez González, "El libro en los claustros", 314-16; Suárez

AQ1 González, "Cistercian Scriptoria", 769-76; Nascimento, "Livros e tradições hispânicas", 1041-58.

${ }^{17}$ R. Gryson suggests C. 1220 in Beati Liebanensis, vol. 1, xvi.

${ }^{18}$ In autumn 2015, UNESCO included Beatus Commentaries in its Memory of the World programme, which recognises and protects world documentary heritage, considering them to be among the most beautiful and original produced by Western medieval civilisation. http://www.unesco.org/new/en/communication-and-information/memory-of-the-world/ register/full-list-of-registered-heritage/registered-heritage-page-5/the-manuscripts-of-the-commentary-to-theapocalypse-beatus-of-liebana-in-the-iberian-tradition/. 
few unillustrated Beatus manuscripts preserved in a complete state. Others include the twelfth-century Poblet Beatus, traditionally believed to have been produced at a Cistercian scriptorium, ${ }^{19}$ and two sixteenth-century copies, ${ }^{20}$ none of which has yet been studied in depth. ${ }^{21}$ In the case of the Alcobaça copy, it seems clear that it was designed from the start not to include images as opposed to simply being unfinished. A comparison of the same chapter in Lorvão and Alcobaça copies, in which the former is illustrated and the latter is not, proves it (Figure 1). We should therefore consider what led to this text being produced without illuminations.

Finally, although it does not contain an iconographic programme, as the Beatus manuscripts generally do, the Alcobaça Beatus does contain two diagrammatic structures and a set of decorated initials, some of which are unfinished. The initials, in their various states of completion, are a very useful tool for increasing our knowledge on the production of manuscripts - particularly the use of colour - in Cistercian scriptoria in general and in Alcobaça in particular.

\section{The Alcobaça Beatus: results of interdisciplinary research}

The Alcobaça Beatus is a manuscript approximately $330 \times 220 \mathrm{~mm}$ in size, comprising 183 folios. It consists of twenty-three quires of four bifolia, with two exceptions: the eighteenth gathering has three bifolia and two single folios, and the last quire is made up of three bifolia and begins with an extra folio (Figure 2). The script is protogothica, typical of the later twelfth to the beginning of the thirteenth century. The text is presented in two columns of thirty-three lines. It is decorated with a set of initials and two diagrammatic designs with exegetical calculating figures for the number 666 and the eight names of the Antichrist.

\section{Textual structure}

A Beatus manuscript may contain up to four different parts: the Genealogical Tables, which trace Christ's ancestry back to Adam and Eve; the Commentary on the Apocalypse compiled by Beatus from a variety of sources; De adfinitatibus et gradibus, taken from the Etymologies of St Isidore (IX: 5); and St Jerome's Commentary on the Book of Daniel. ${ }^{22}$ The second of these, the Commentary on the Apocalypse, can also have several parts: a preface ostensibly written by Beatus that may in fact have largely been appropriated from other sources; a first prologue attributed to St Jerome in the text itself, which was present in many Vulgate copies of the Apocalypse; a second prologue consisting of an extract of Jerome's letter to Anatolius, which was later used for Jerome's introduction to the Commentary on the Apocalypse by Victorinus of Pettau; and the Interpretatio (also

${ }^{19}$ Salamanca, Biblioteca de la Universidad, ms. 2632.

${ }^{20}$ El Escorial, Biblioteca del Real Monasterio, f.I.7; and Biblioteca Apostolica Vaticana, Vat. Lat. 7621.

${ }^{21}$ There are still other copies that may originally have been without illustrations, such as the fragmentary copy made for the monastery of San Pedro de las Dueñas at the scriptorium of Sahagún (Sts Facundus and Primitivus, León). See Suárez González, "Los otros beatos", 86. Others, instead, show blank spaces for illustrations that were not realised. See Gryson, Beati Liebanensis, vol. I, XVII.

${ }^{22}$ The full Beatus text is composed of a set of texts and materials, with different origins and purposes, which ended up being combined into a single work that was uneven in form. See Díaz y Díaz, "Un nuevo comentario hispano", 31. 

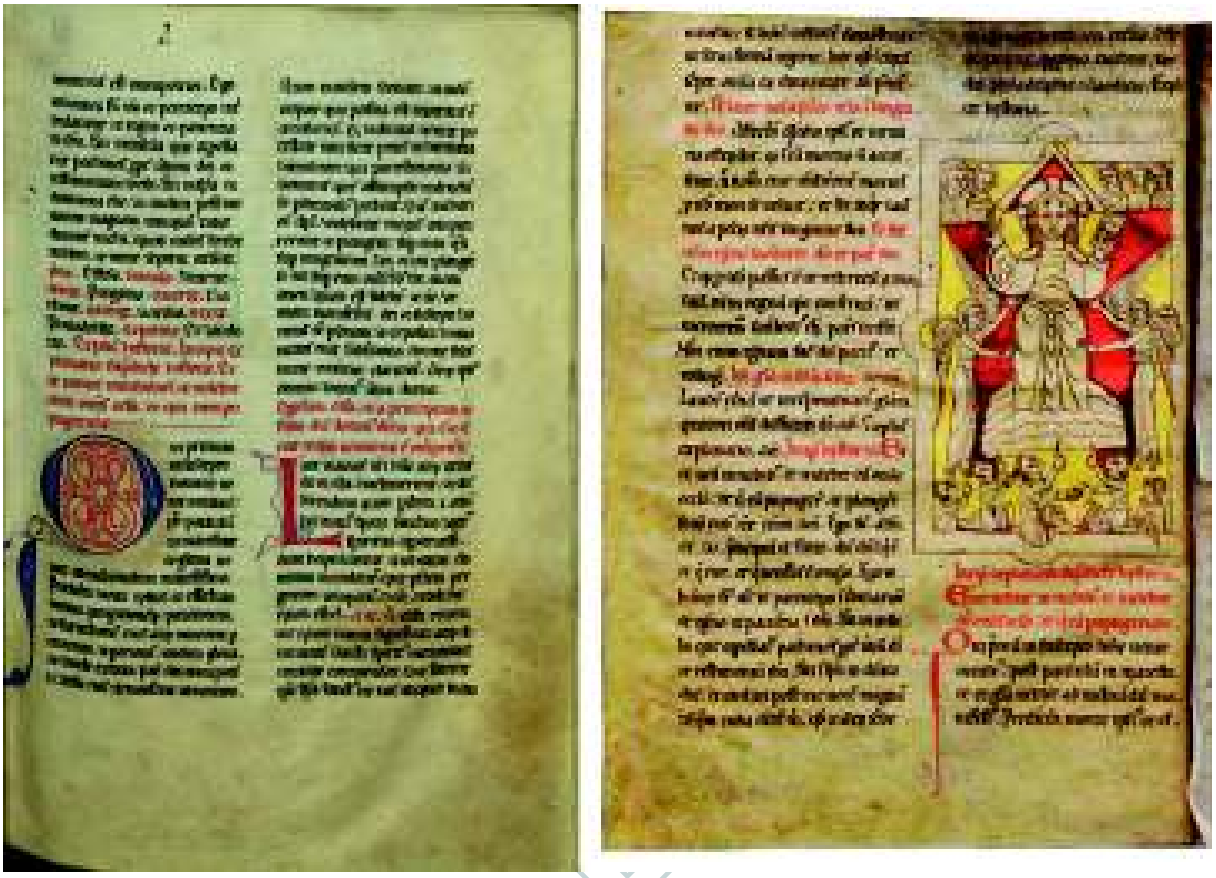

Figure 1. Comparison of the Lorvão and Alcobaça Beatus manuscripts that shows how the former is illustrated whereas the latter was not intended to be illustrated. Left: Alcobaça Beatus. Lisbon, Biblioteca Nacional, MS Alc. 247, f. 16. Right: Lorvão Beatus. Lisbon, Arquivo Nacional da Torre do Tombo, Ordem do Cister, Mosteiro de Santa Maria de Lorvão, Liv. 44, f. 12v.

known as the Summa dicendorum), a summary of the twelve books of the Commentary copied largely from Tyconius.

The Commentary itself comprised twelve books and three interpolated passages from Isidore, Augustine and Gregory of Elvira. The concluding section of the Commentary is the Explicit codex, which contains definitions of the terms "codex", "book", "volume", "folio" and "page", again taken from Isidore's Etymologies. ${ }^{23}$

Of the four elements that a Beatus may have, the Alcobaça manuscript contains only the second - that is, the Commentary, which includes the introductory materials and Explicit codex. However, it differs from other copies of the Beatus in its arrangement of these texts, which appear in the following sequence: Prologue I, Prologue II, Interpretatio, Preface, Prologue I, Prologue II, the twelve books of the Commentary with the three interpolations, and Explicit codex (Figure 3). This ordering of the texts is highly unusual, as is the fact that Prologues I and II are repeated. ${ }^{24}$ In fact, the organisation is unique among Beatus manuscripts. From the viewpoint of the sequence of contents then, the Alcobaça Beatus differs from the Lorvão Beatus, the codex which is traditionally considered to be its model.

\footnotetext{
${ }^{23} \mathrm{For}$ the structure and content of Beatus manuscripts see Romero-Pose, "The Beatus Commentary", 53-104, and Díaz y Díaz, "Un nuevo comentario hispano", 31-56.

${ }^{24}$ Still, a parallel to the repetition of Prologues I and II in the Alcobaça Beatus is to be considered. It is the repetition of the paragraph "De Antichristo" in the most recent and most corrupted branch of the Beatus tradition (Branch llb). See Beato 

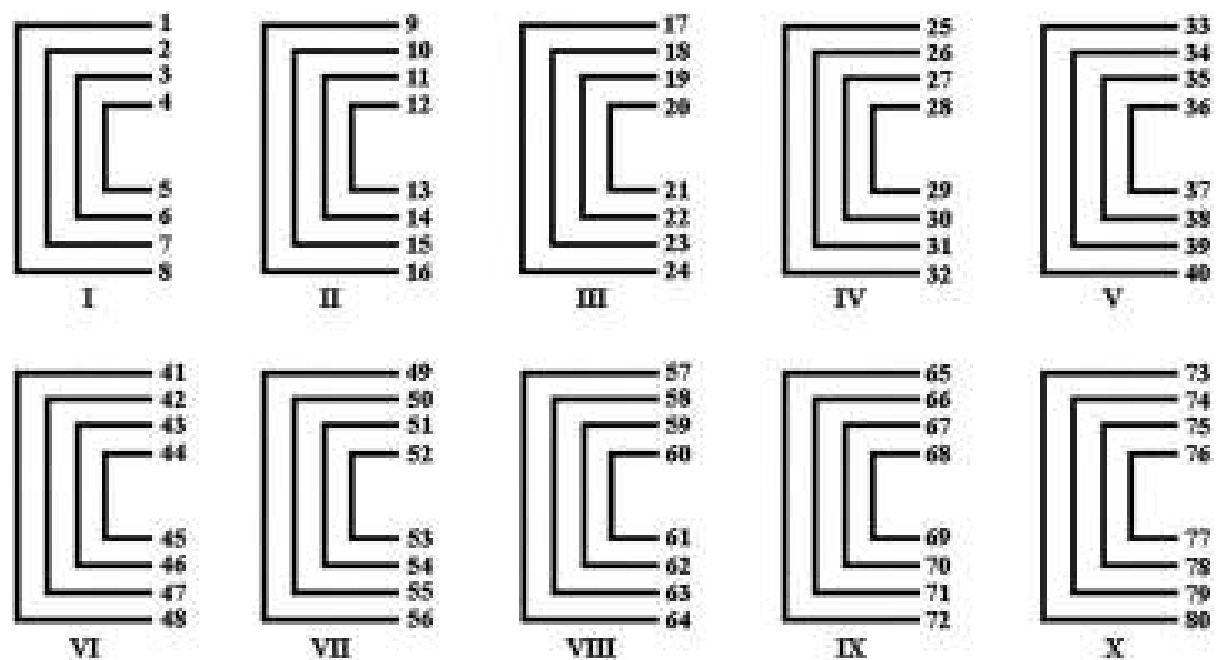

240
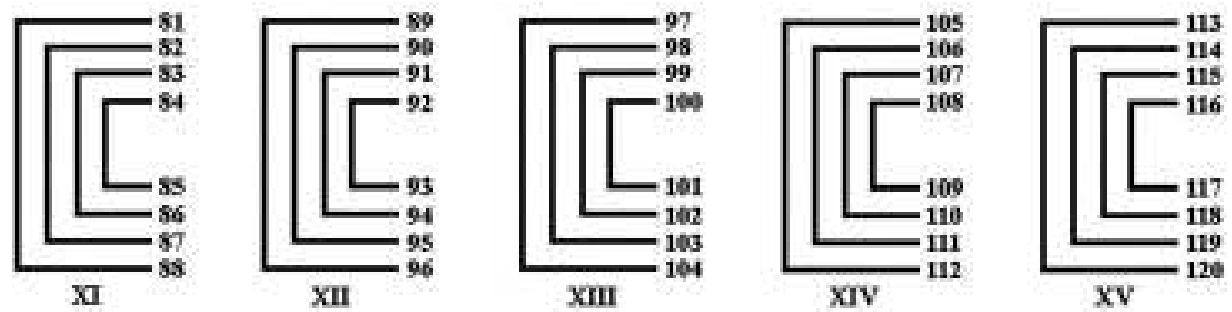

250
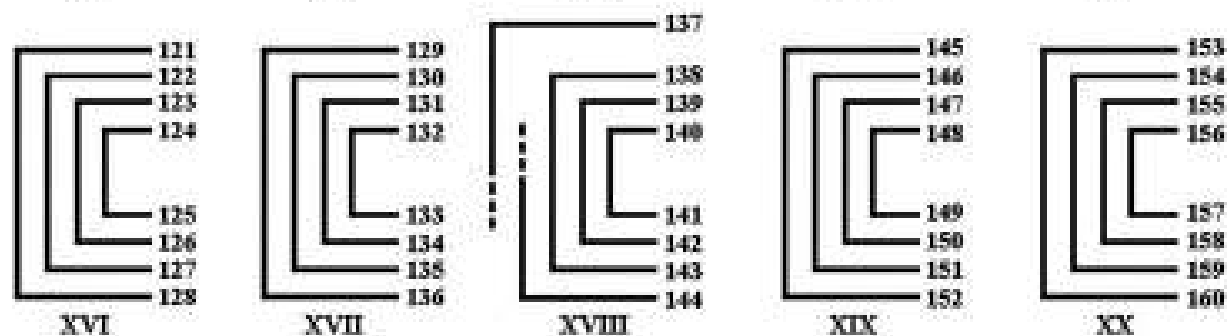

260
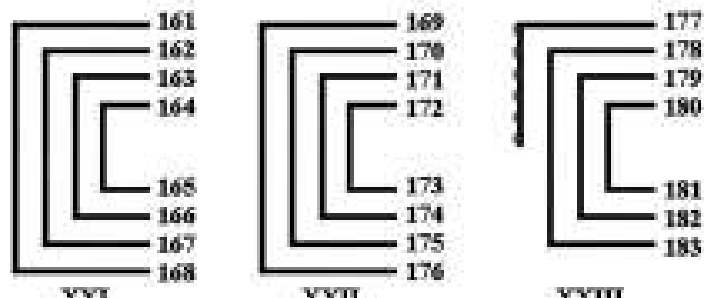

XXIII

Figure 2. Scheme of the construction of the quires from the textblock of the Alcobaça Beatus.

\section{The decoration of the manuscript}

Of the four elements that could form a Beatus manuscript, two were usually accompanied by iconographic programmes: the Commentary on the Apocalypse and Jerome's Commentary on Daniel. In the Lorvão Beatus, which belongs to the Branch I of the Beatus pictorial 


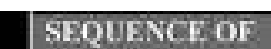

BEATUS

LORVÃO BRMTUS

AlCOBACA BEATUS

COMMIENTARY

Prologus 1

f. If

Prologus II

f. It

Interpretatio

(Summa Dicendorum)

f. Iv

Praefatio

Praefatio

Praefatio

f. $12 \mathrm{v}$

\begin{tabular}{|ll|}
\hline Prologus I & $\begin{array}{l}\text { Prologus I } \\
\text { C. Iv }\end{array}$ \\
\hline Prologus II & $\begin{array}{l}\text { Prologus II } \\
\text { C. Iv }\end{array}$ \\
\hline $\begin{array}{l}\text { Interpretatio } \\
\text { (Summa dicendorum) }\end{array}$ & $\begin{array}{l}\text { Interpretatio } \\
\text { (Summa dicendorum) } \\
\text { f. } 2 r\end{array}$ \\
\hline $\begin{array}{l}\text { Beati in Apocalipsin Libri } \\
\text { XII }\end{array}$ & $\begin{array}{l}\text { Beati in Apocalipsin Iibri } \\
\text { XII } \\
\end{array}$ \\
\hline
\end{tabular}

Prologus I f. $12 \mathrm{v}$

Prologus II
f. $13 \mathrm{r}$

\begin{tabular}{|c|c|c|}
\hline $\begin{array}{l}\text { Beati in Apocalipsin libri } \\
\text { XII }\end{array}$ & $\begin{array}{l}\text { Beati in Apecalipsin Iibri } \\
\text { XII } \\
f_{1} 12 \mathrm{r}\end{array}$ & $\begin{array}{l}\text { Beati in Apocalipsin libri } \\
\text { XII } \\
\text { f. } 13 \text { r }\end{array}$ \\
\hline Interpolatio I & Interpolatio I & Interpolatio I \\
\hline $\begin{array}{l}\text { Prologus lihri II "De } \\
\text { eeclesia et sinsgoga" } \\
\text { (Isid, Etim, VII-VIII) }\end{array}$ & $\begin{array}{l}\text { Prologus libri II "De } \\
\text { ecclesia et sinagoga" } \\
\text { f. } 29 \mathrm{y}\end{array}$ & $\begin{array}{l}\text { Prologus libri II “De } \\
\text { ecelesia et sísagoga" } \\
\text { f. } 31 \mathrm{tr}\end{array}$ \\
\hline Interpolatio II & Interpolatio II & Interpolatio II \\
\hline $\begin{array}{l}\text { De Antichristo } \\
\text { (Aug., De civitafe Dei, XX, } \\
\text { 19) }\end{array}$ & $\begin{array}{l}\text { De Antichristo } \\
\text { f, } 38 \mathrm{f}\end{array}$ & $\begin{array}{l}\text { De Antichristo } \\
\text { f. } 39\end{array}$ \\
\hline Interpolatio III & Interpolatio III & Isterpolatio III \\
\hline $\begin{array}{l}\text { De arca Noe } \\
\text { (Greg. Tractatus de Arca } \\
\text { Noe) }\end{array}$ & $\begin{array}{l}\text { De area Noe } \\
\text { f. } 82 \mathrm{r}\end{array}$ & $\begin{array}{l}\text { De area Noe } \\
\text { f. } 74 \pi\end{array}$ \\
\hline $\begin{array}{l}\text { Explicit codex } \\
\text { (Isid. Erim. VI, 13-14) }\end{array}$ & $\begin{array}{l}\text { Explicit codex } \\
\text { f. } 219 \mathrm{r}\end{array}$ & $\begin{array}{l}\text { Explicit codex } \\
\text { f. } 183 r\end{array}$ \\
\hline
\end{tabular}

Figure 3. Comparison of the Beatus Commentary general sequence with the Lorvão and Alcobaça copies.

tradition, an iconographic programme accompanies the Commentary on the Apocalypse, but not the Commentary on Daniel.

The Alcobaça Beatus, however, is unillustrated, even though a gloss on folio 60 describes the supposed existence of an image that illustrated the Message to the Church 

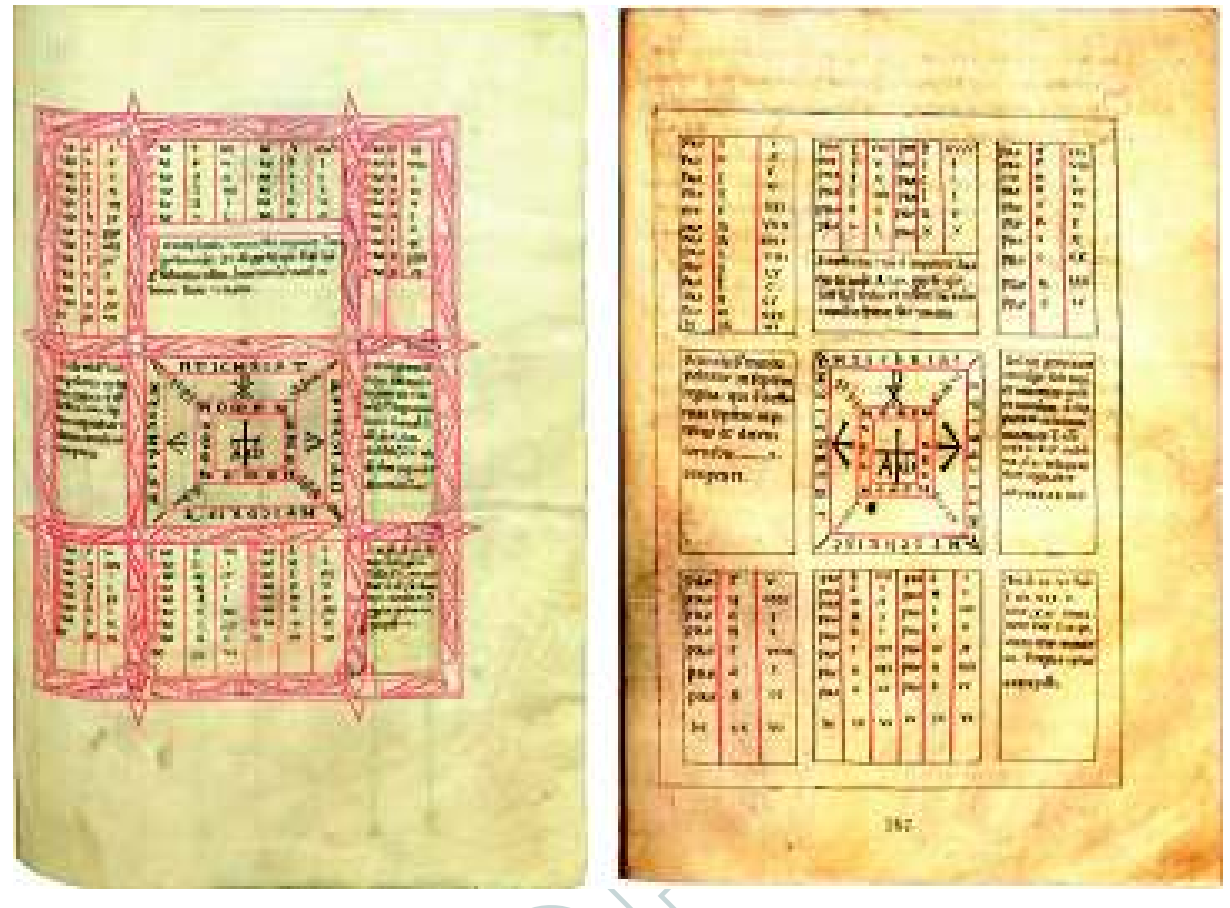

Figure 4. First Antichrist table. Alcobaça Beatus. Lisbon, Biblioteca Nacional, MS Alc. 247, f. 144 and Lorvão Beatus. Lisbon, Arquivo Nacional da Torre do Tombo, Ordem do Cister, Mosteiro de Santa Maria de Lorvão, Liv. 44, f. 166.

of Thyatira. ${ }^{25}$ However, it does contain the two Tables of the Antichrist, which present the equation of the eight names of the Antichrist with the number 666 (Figures 4 and 5). ${ }^{26}$

The tables are located on the recto and verso of folio 144, which is an independent folio integrated into the eighteenth quire (Figure 2). As in most Beatus manuscripts, these tables have a purely textual content but are enriched with ornamentation. The first table consists of a rectangle divided into nine parts, with the central panel displaying the name of the Antichrist and the cross of Oviedo - that which, according to the legend, Pelagius of Asturias carried at the first battle of the Reconquista and which was turned into a common motif in medieval Iberian iconography - with the Alpha and Omega. The rectangles are separated by bands decorated with acanthus-leaf motifs, using only red and black ink. It is a very similar composition to that found in the Lorvão manuscript, which, however, lacks the foliate motif (f. 167r). ${ }^{27}$

\footnotetext{
${ }^{25}$ It also appears in the Lorvão Beatus (f. 64v), although in this case is located within the text itself. Its content is related to Jezebel and the idol's immolation, elements which are not depicted in the Lorvão image; they are illustrated, however, in the illustration of this passage in the Beatus of Burgo de Osma. This manuscript, however, does not contain the abovequoted gloss in Latin on the image. According to Peter Klein, this means it is possible that both manuscripts, Osma and Lorvão, derive from a common prototype. See Klein, Beato de Liébana, 70-1.

${ }^{26}$ Revelation 13: 18; Beatus, 6: 5. The part of the Commentary where these tables are included drew on Jerome's edition of the Commentary on the Apocalypse by Victorinus of Pettau. See Williams, "Beatus of Burgo de Osma", 125. On the Antichrist Tables see also Klein, Der ältere Beatus-Kodex, 153-62; Neuss, Die Apokalypse des HI. Johannes, vol. 1, 73-80 and vol. 2, cxlv-cxlvii.

${ }^{27}$ Klein, Beato de Liébana, 101-2.
} 

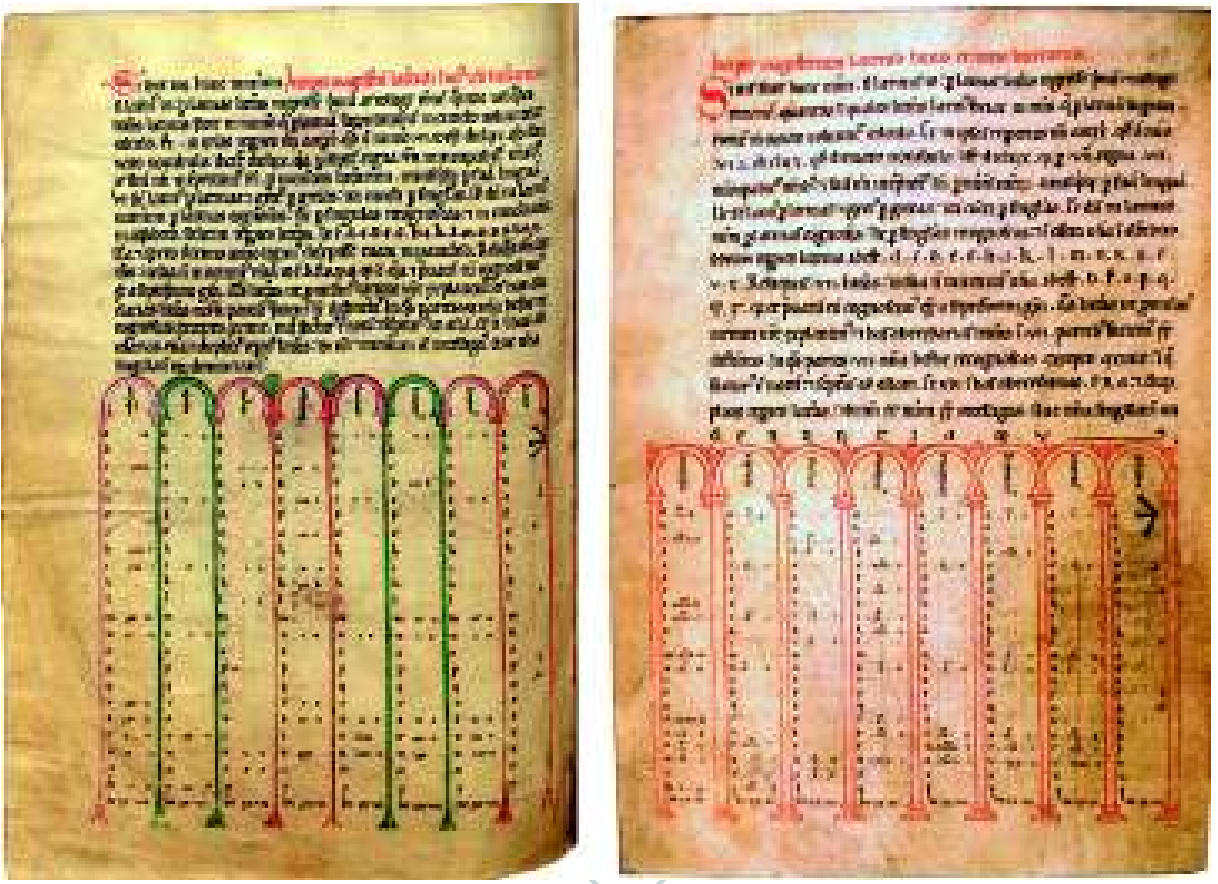

Figure 5. Second Antichrist table. Alcobaça Beatus. Lisbon, Biblioteca Nacional, MS Alc. 247, f. 144v and Lorvão Beatus. Lisbon, Arquivo Nacional da Torre do Tombo, Ordem do Cister, Mosteiro de Santa Maria de Lorvão, Liv. 44, f. 166v.

The second table is preceded by the explanatory text Incipit magister laterculi huius et ratio litterarum (the master of this list and the value of the letters), ${ }^{28}$ which is copied in a single column, deviating from the two-column organisation of the rest of the text. This table consists of an arcade formed by eight horseshoe arches, each of which houses one of the names of the Antichrist. It has a more varied range of colours than the first table, alternating green, red and pink. The composition here can also be compared to that of the Lorvão Beatus; in Alcobaça the architectural frame is simpler and the chromatic range is wider. The Antichrist Tables in both Portuguese codices demonstrate similarities with those in the Burgo de Osma Beatus of 1086 and the twelfth-century Corsini Beatus, which were produced in the scriptorium of the Leonese monastery of Sahagún. ${ }^{29}$ However, these Leonese copies lack certain elements of the Portuguese compositions which are unique among the Beatus manuscripts, such as the Oviedo Cross with the alpha and omega in the centre, and the three devices that surround the cross: a monogram of Christ (chi rho) above, and two arrow-like signs to each side. In the case of the recently discovered Geneva Beatus, which was made in southern Italy in the eleventh century and exhibits many iconographic similarities to the Lorvão Beatus, the similarities do not apply to the Antichrist Tables. The Geneva manuscript only includes the first table

\footnotetext{
${ }^{28}$ Williams, A Spanish Apocalypse, 195.

${ }^{29}$ Osma Beatus: Burgo de Osma, Catedral, Biblioteca Capitular, Cod. 1, f. 127r-v. See Shailor, "The Beatus manuscript", 2952. Corsini Beatus: Rome, Biblioteca dell'Accademia Nazionale dei Lincei e Corsiniana, ms. 369 (40.E.6), ff. 142r (Table I), $143 r$ (Explanatory Text), 144r (Table II).
} 
(along with the explanatory text), and it is entirely different from the Portuguese and Leonese examples in terms of structure and decoration. ${ }^{30}$

Besides the Antichrist Tables, the Alcobaça Beatus also contains decorated initials. The above-mentioned deviation from the standard arrangement of texts is reflected in the decoration of this codex. Only the first three quires of the manuscript have a complete set of initials, which mark the beginnings of the prologues, the preface and certain individual sections in the Interpretatio. However, they gradually disappear in the following quires (Figure 6). ${ }^{31}$

Toward the beginning of the manuscript, these ornate letters range between four and nine lines in height, but from folio $47 \mathrm{v}$ onwards they are undecorated and smaller, occupying just two lines of text. There is one exception: the initial marking the beginning of the lapidary on folio $175 \mathrm{r}$ - which at the very least implies that this textual material was considered crucial to the manuscript.

This means that the most richly ornamented initials are located in precisely the part of the codex that exhibits anomalies in the textual sequence. In this regard, folio $12 \mathrm{v}$ should be highlighted. It is the most lavishly decorated folio of the entire manuscript, with two large initials marking the beginning of the Praefatio and Prologue I; the manuscript should have begun with these two parts, but does not. This in fact constitutes one of the data about which we will speculate in our later discussion.

There are several types of decorated initials: framed initials with painted backgrounds, initials without painted backgrounds but with the same type of ornamentation, and painted initials without decorative motifs. The decorated initials exhibit similarities with those in other illuminated manuscripts from Alcobaça. The manuscripts that have a comparable set of decorated initials include Alc. 253, a Missal; ${ }^{32}$ Alc. 360, which contains Origen's Homiliae in Leviticum, Numerum, Josue et Judices translated by Tyrannius Rufinus; ${ }^{33}$ Alc. 402 , which is a Tractatus de Evangelio Sancti Iohannis by St Augustine; ${ }^{34}$ Alc. 412, a Homiliarium; ${ }^{35}$ and Alc. 426, which contains several didactic texts such as Papias's Elementarium doctrinae rudimentum and Rabanus Maurus's De numeris. ${ }^{36}$

\section{The molecular palette and colour construction}

Previous studies on the scriptoria of the Portuguese monasteries of São Mamede de Lorvão, Santa Cruz de Coimbra and Santa Maria de Alcobaça between the end of the twelfth and the first quarter of the thirteenth centuries found that these monasteries used the same colourants in this period. ${ }^{37}$ This colour palette was composed of vermilion, red lead (also known as minium), orpiment, lac dye, lapis lazuli, indigo, green copper proteinate (also known as bottle green), lead white, carbon and bone black. Azurite was very seldom found, and never in decorated initials. Overall, these colours were applied mostly as pure pigments. Chalk and gypsum were sometimes admixed with other pigments, such

${ }^{30}$ Geneva, Bibliothèque de Genève, Ms. Lat. 357, f. 217, available at: http://www.e-codices.unifr.ch/en/list/one/bge/lat0357). See Hochuli Dubuis and Jeger, "Un Beatus découvert", 11-29; Klein, "Remarques sur le manuscript bénéventin", 3-38; Reynolds, "Apocalypses New", 1-44; Williams, Visions of the End in Medieval Spain.

${ }^{31}$ Initials appear on folios 5v, 7r, 8r, 10r, 12r, 12v, 13v, 15r, 15v, 16r, 18r, 18v, 19v, 21v, 22v, 23r, 25r, 31r, 47v, 95r.

${ }^{32}$ Inventário dos códices, 175.

${ }^{33}$ Ibid., 199

${ }^{34}$ Ibid., 217.

${ }^{35}$ Ibid., 223.

${ }^{36}$ Ibid., 225-6.

${ }^{37}$ Melo et al., "Colour: An Interdisciplinary Approach"; Melo, Castro and Miranda, "Colour: between Beauty and Meaning". 

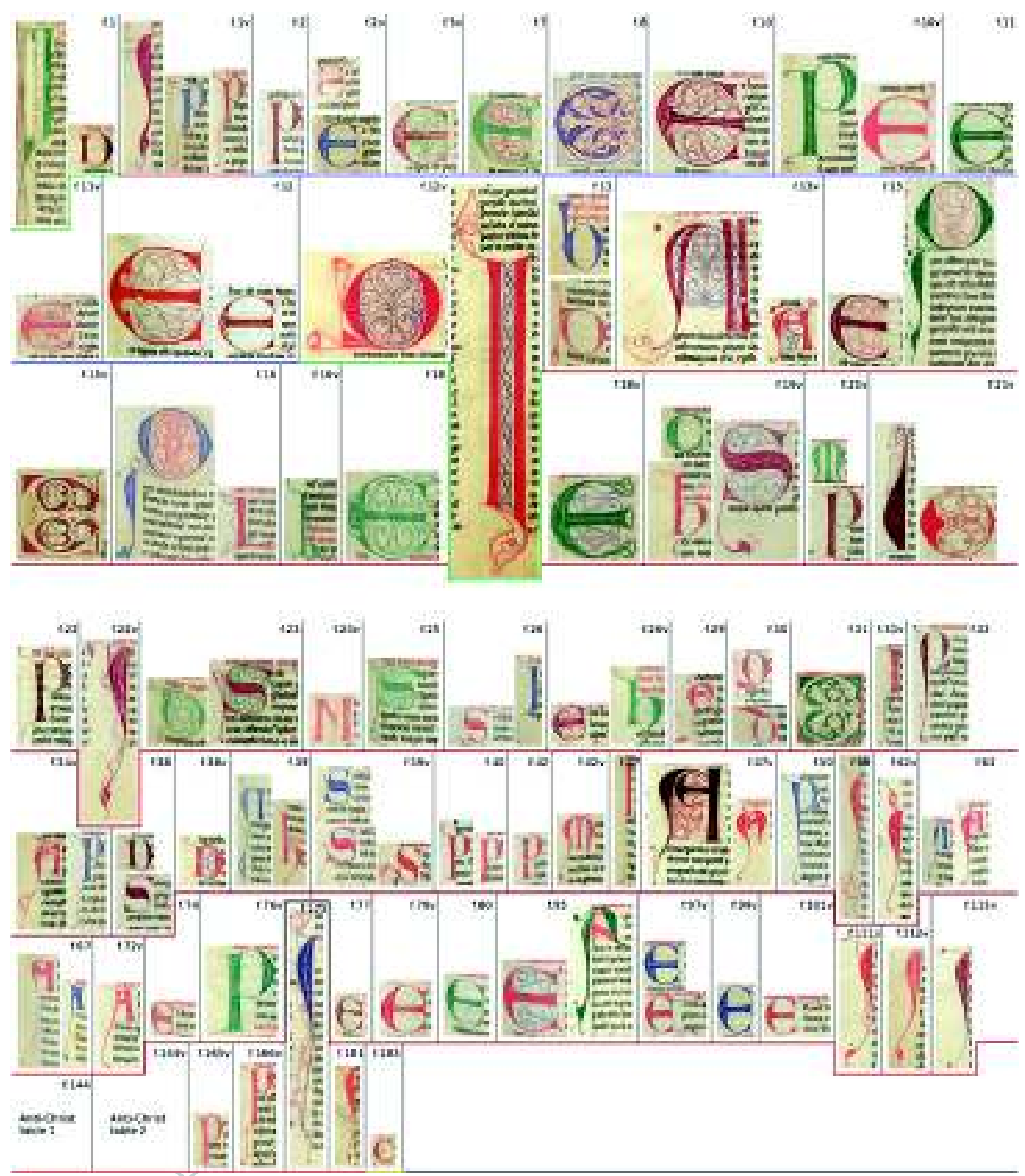

Figure 6. Alcobaça Beatus initials in their actual proportion (only the ones that are larger than two lines of the text). The line below the initials is in different colours in order to represent the distinct sections of the texto: Prologue I (green) - Prologue II (carmim) - Interpretatio (blue) - Prologue I (green) - Prologue II (carmim) - the twelve books with the three interpolations - Explicit codex (yellow).

as vermilion or lac dye, as fillers. The use of gypsum in lac dye paints was found to be characteristic of the scriptorium at Alcobaça in particular. A proteinaceous binder was systematically identified in all three collections. ${ }^{38}$

Within this framework, the Lorvão Beatus emerges as an exception. ${ }^{39}$ Its colour palette is essentially confined to orpiment, red lead and vermilion. ${ }^{40}$ Molecular analysis allowed

${ }^{38}$ Melo, Castro and Miranda, "Colour: between Beauty and Meaning".

${ }^{39}$ Miguel et al., "A study on red lead degradation"; Melo et al., "Colour: An Interdisciplinary Approach"; Melo, Castro and

Miranda, "Colour: between Beauty and Meaning"; Miranda and Melo, "Secrets et découvertes en couleur".

${ }^{40}$ Ibid., 20-4; Melo et al. "Colour: An Interdisciplinary Approach", 164-5. 
us to establish that some of the dark orange shades in the backgrounds of certain illuminations, which art historians had interpreted as shading effects, were, in fact, degradation. As red lead undergoes the process of deterioration, its bright orange changes to dark grey, which is occasionally lustred. ${ }^{41}$ We now know that the manuscript's colours would originally have been even more vibrant.

The paints used in the Alcobaça Beatus are entirely consistent with those of other manuscripts produced in Portuguese monasteries: the colourants, fillers and binding media are all identical (Figure 7). The colour palette includes some of the highestquality colourants available during the Middle Ages: lapis lazuli from Afghanistan; vermi505 lion, most likely obtained from the Spanish mines of Almadén; synthetic red and white leads; luminous lac dye imported from India or China; carbon and bone black; and, finally, bottle green. Our main analytical results for each colour identified in the Alcobaça Beatus can be observed in Figures 8, 9 and 10 (see Appendix). ${ }^{42}$

These pigments were carefully ground and mixed with a proteinaceous matrix. This glue could have been based on a single protein source, such as parchment or egg white, or a mixture. Fillers such as calcium carbonate were also detected, most often admixed with vermilion. Particularly interesting was the identification of gypsum in the lac dye paints (Figure 10). This mixture has been found systematically in manuscripts from the Alcobaça scriptorium. The Lorvão scriptorium only used calcium carbonate as filler, and gypsum has been identified in just one manuscript from Santa Cruz de Coimbra. Taking this into account, we propose that this specific colour formulation is characteristic of Alcobaça.

Once the overall data were compared, a subtle difference emerged: there was more variation in the paint colours, appearance and molecular signature than usual. In our previous studies on Portuguese monastic manuscripts, we found that their paints tended to be very similar in formulation within a given book, contrary to what is normally found, for example, in fifteenth-century Books of Hours, which used many variations in the composition of the paints. In the Alcobaça Beatus, the colours are not as homogeneous as those found in the other twelfth- and thirteenth-century Portuguese manuscripts under consideration. This may be because, for the first time, we are studying an unfinished painted work.

We also noticed that certain colours, which are usually found in a very good state of preservation in Portuguese manuscripts, such as vermilion, exhibited unexpected darkening in the Alcobaça Beatus. ${ }^{43}$ Here, the bottle green, which is typically shiny, displayed a matte finish which was closer to malachite than a saturated glassy green. These points are explained by greater degradation, as was confirmed by the unusually high percentage of calcium oxalate detected in the green colours, which is a product of degradation (Figure $8 \mathrm{c}) .{ }^{44}$ Extensive darkening of the lead pigments (orange and white colours) was also observed (Figure 11).

\footnotetext{
${ }^{41}$ Miguel et al., "A study on red lead degradation", 1966-73.

${ }^{42}$ On the provenance of these materials, see Miranda and Melo, "Secrets et découvertes", 9-10.

${ }^{43}$ Lead white was often identified in an admixture with vermilion, the degradation of the former being well documented in works of art, including the Alcobaça production $\left(12^{\text {th }}-13^{\text {th }}\right.$ c.). See Muralha, Miguel and Melo, "Micro-Raman Study", 1737-46.

${ }^{44}$ Weddellite and whewellite - the dehydrated and monohydrate forms of $\mathrm{CaC}_{2} \mathrm{O}_{4} \cdot \mathrm{H}_{2} \mathrm{O}$, respectively - have been reported as the most common calcium oxalates found in works of art. The underlying principle behind the presence of oxalates is still under investigation, but they have been linked to the alteration over time of binding media. It is believed that calcium oxalate is one of the final products of a radical chain reaction, through its interaction with the calcium present in the support. See Melo et al. "Colour degradation in medieval manuscripts".
} 

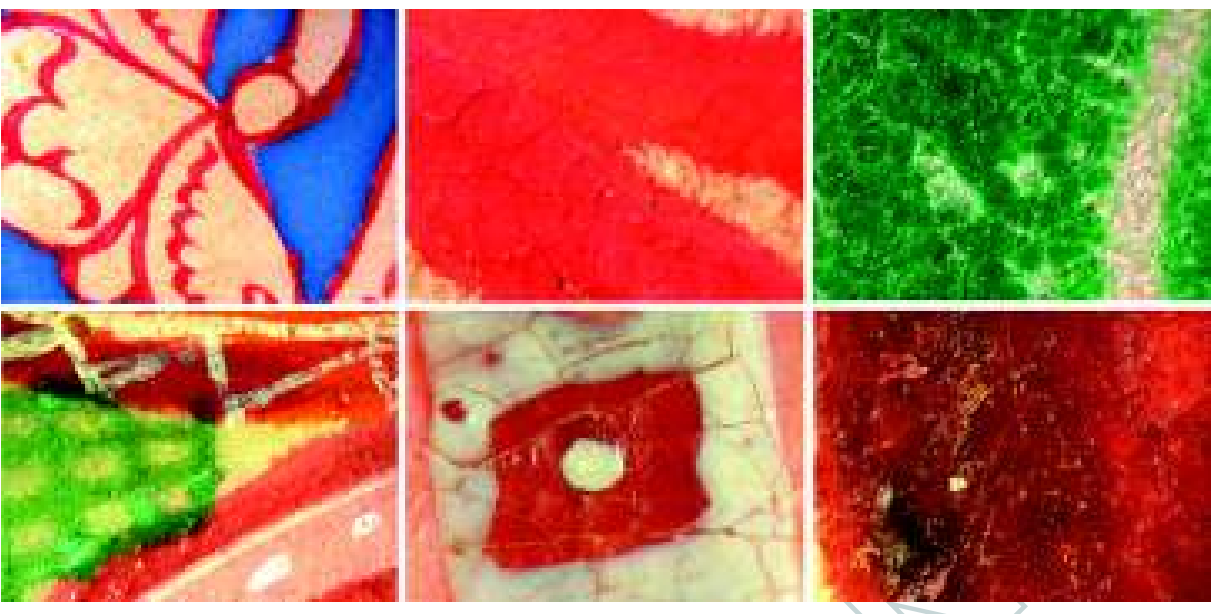

Figure 7. Paint details from the Alcobaça Beatus. From top to bottom: fols. 8 (lapis lazuli in the background and lac dye for the outline), 12v (vermilion), 10v (bottle green), 144v (highlights in lead white on several colours), $144 \mathrm{v}$ (highlights in lead white with a pink background) and $21 \mathrm{v}$ (lac dye).
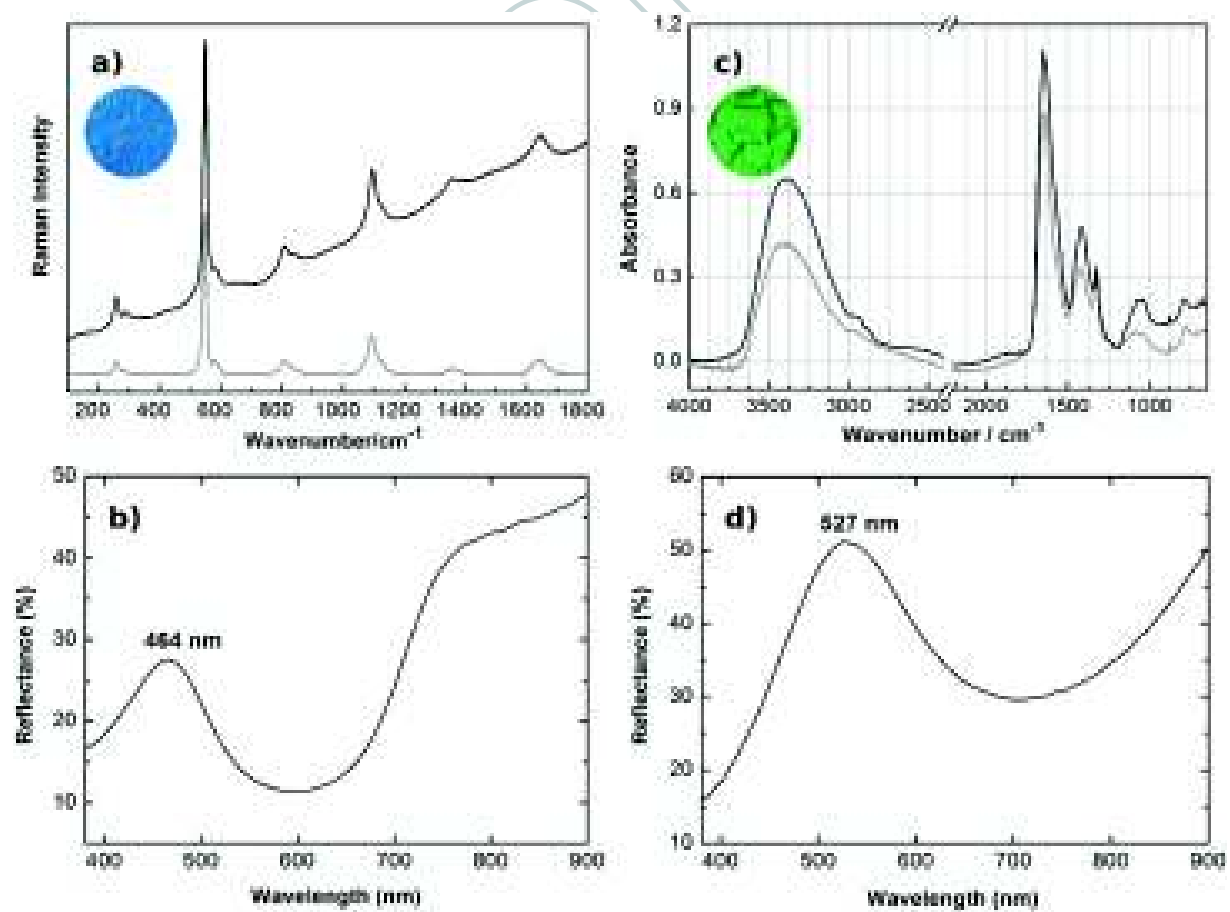

Figure 8. Molecular characterisation of blue and green paints: (a) Raman spectra of a blue initial, f. 8 , with a lapis lazuli reference in grey; (b) reflectance spectrum of a blue initial, f. 8; (c) infrared spectra of green initial, f. 18, with bottle green from MS Alc. 249, f. 125v, in grey; (d) reflectance spectrum of a green initial, f. $18 \mathrm{v}$. 

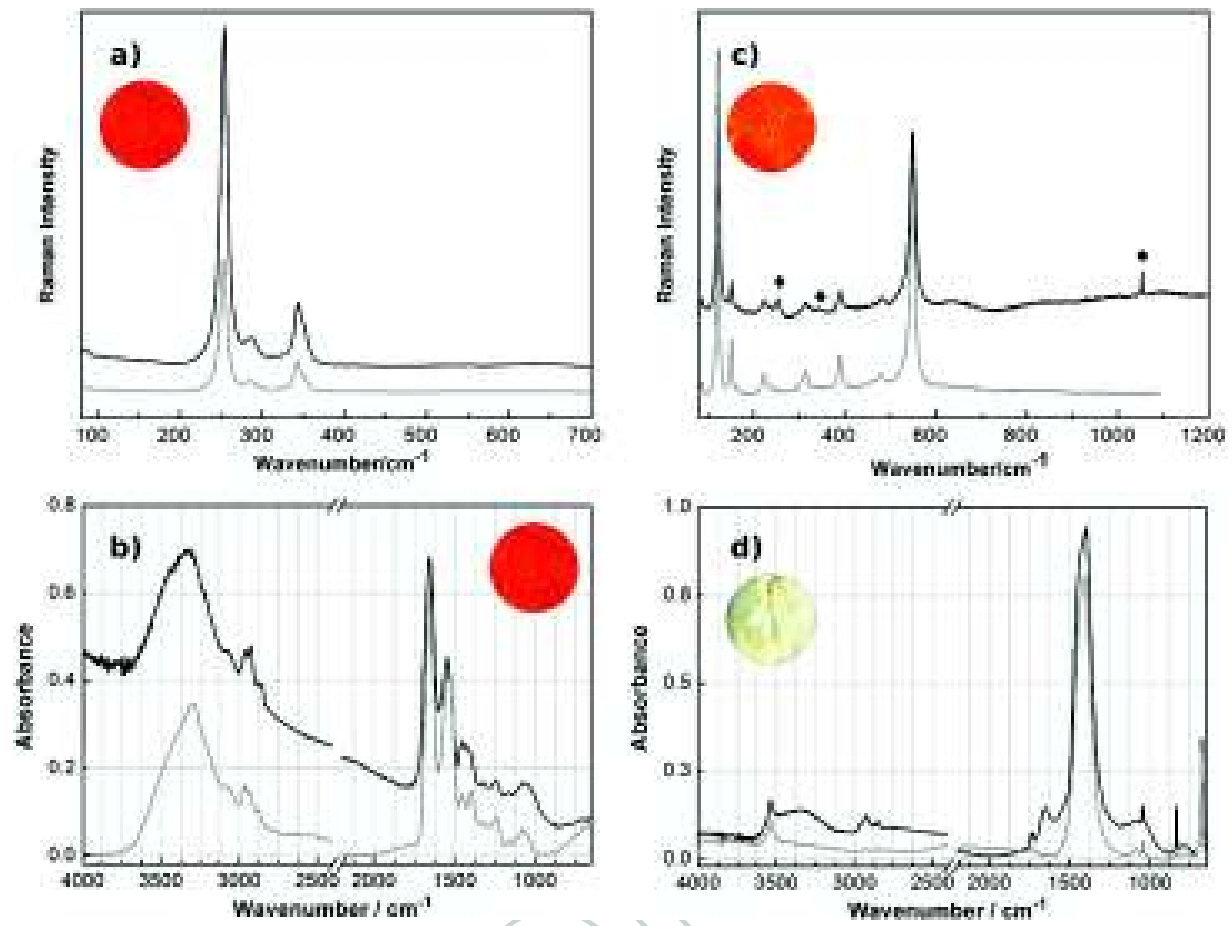

Figure 9. Molecular characterisation of red, orange and white paints: (a) Raman spectra of a red initial, f. 12v, with a vermilion reference in grey; (b) infrared spectrum of a red initial, f. 112v, with an egg white reference in grey; (c) Raman spectra of orange paint (with the presence of vermilion and lead white) with a red lead reference in grey; (d) infrared spectra of lead white, f. 144v, with a lead white reference in grey.

\section{The making of the initial letters of the Alcobaça Beatus}

Our previous studies on colour in Portuguese monastic production during the twelfth and thirteenth centuries enables us to conclude that the Alcobaça Beatus is a manuscript in which some decorated initials were left unfinished, and this provides us with an opportunity to learn more about the precise sequence of steps used to create Portuguese illuminations in this period. Taking a closer look at a selection of unfinished initials in the Alcobaça Beatus and comparing them with those of the finished works from the Alcobaça scriptorium led us to propose that the main sequence of steps in creating illuminated initials was consistent across the manuscripts (Figures 12-15). This hypothesis is further confirmed when we scrutinise the only other Alcobaça manuscript with unfinished initials, Alc. 360, which has two (Figure 16).

Until now, for the Alcobaça scriptorium, the sequence of steps used to complete these lavish works in colour was more guessed at than accurately determined, and thus this study of the Alcobaça Beatus offers a rare glimpse "behind the scenes" into Cistercian artistic production. Such a study provides valuable information about the traditional craft of manuscript production - the enhancement of beauty and of durability - as will be described below. 

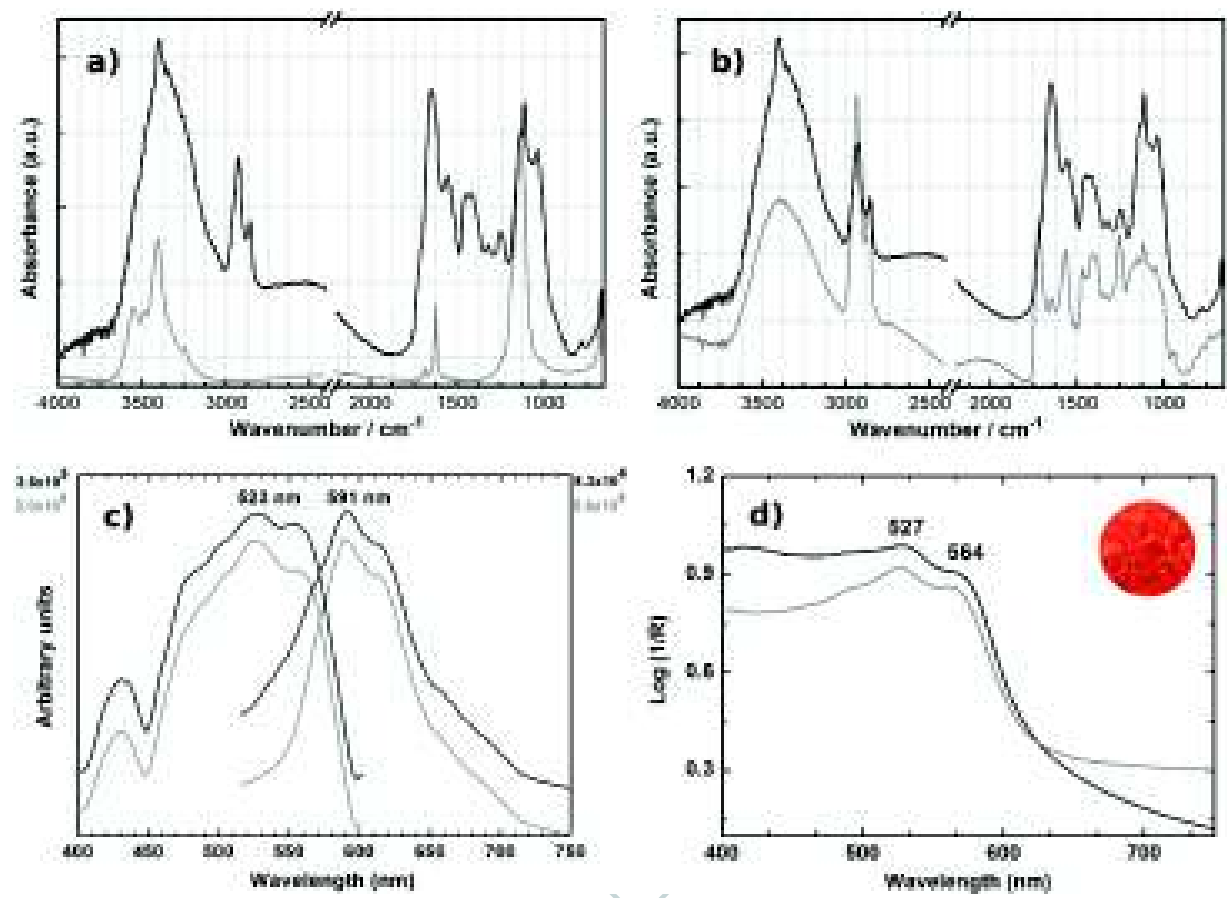

Figure 10. Molecular characterisation of the dark red paints: (a) infrared spectra of a dark red initial, f. 15v, with a gypsum reference in grey; (b) infrared spectra of a dark red initial, f. 15v, with a lac dye reconstruction reference in grey; (c) emission and excitation spectra of a dark red initial, f. 21v, with a lac dye reconstruction reference in grey; (d) reflectance spectra of a dark red initial, f. 15v, with a lac dye reconstruction reference in grey.

A medieval technical treatise which provides relevant information is the mid-fifteenthcentury Göttingen Model Book (hereafter, GMB). ${ }^{45}$ One of the aims of the present study is to assess whether the techniques described in the GBM were already in place in Portugal in the twelfth and thirteenth centuries.

The GMB outlines the fundamental steps involved in the creation of manuscript initials, which may be summarised as follows: (1) drawing with a thin line and applying the main colours, (2) outlining, (3) shadowing and (4) highlighting. In Figure 16, we demonstrate that these steps can be noted in the unfinished initials. We further compared the information provided by the GMB with that in the treatise Liber diversarum arcium, which Mark Clarke suggests was largely written around 1430, using an original core written around 1300, and which provides unique and precise instructions on how to prepare colour paints for illumination, describing which colours can be used to shadow or highlight. ${ }^{46}$

\footnotetext{
${ }^{45}$ Very few instruction books for medieval illumination are available to us, at least of European origin; Lehmann-Haupt, The Göttingen Model Book, 11-12, praised it thus: "Never, in well over forty years spent in the study of books and manuscripts, had I seen any work to compare with this small gem." "(It is) the only model book to contain both verbal instructions and pictorial models in colour that explain the production of decorative illumination in a closely integrated sequence of steps."

${ }^{46}$ Clarke, The Montpellier Liber diversarum arcium, 11.
} 


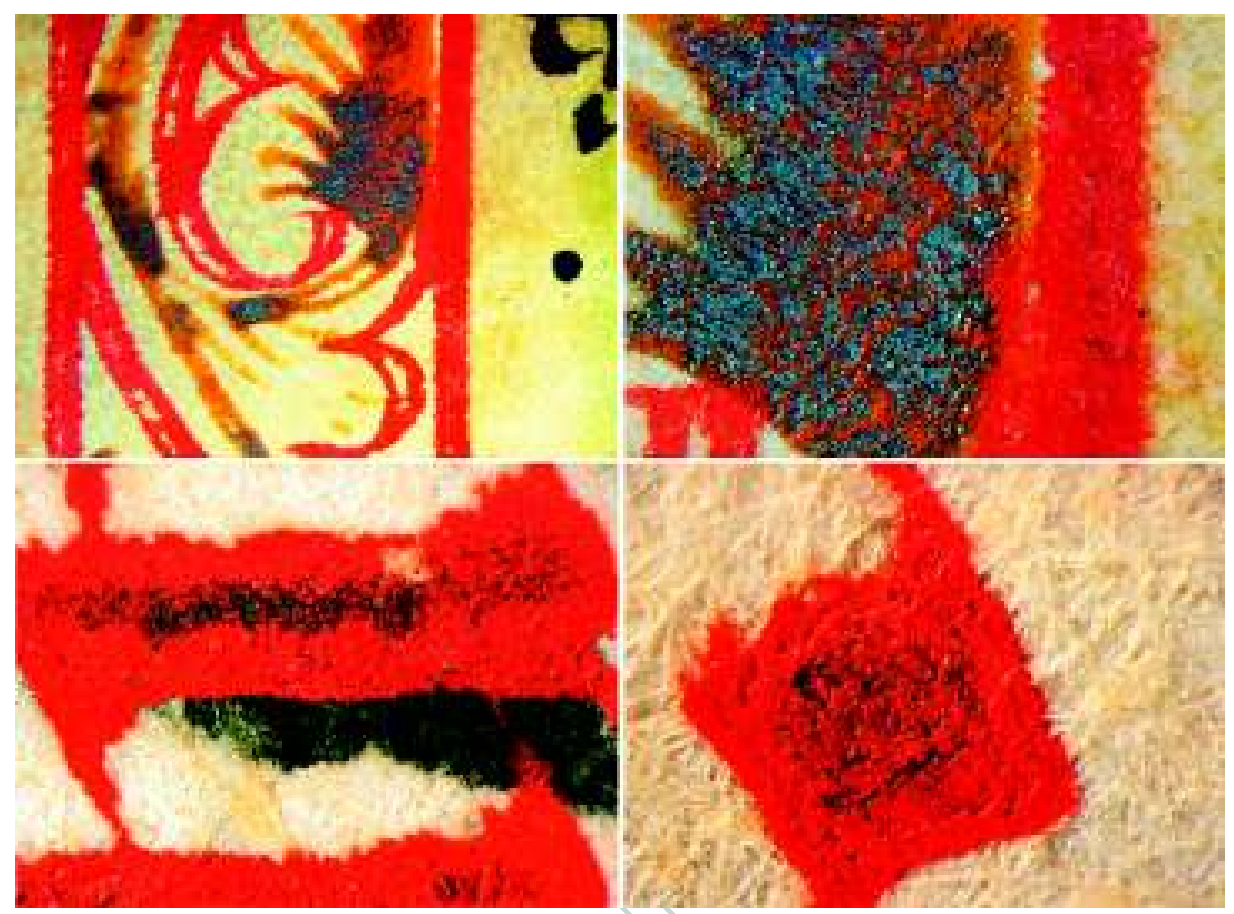

Figure 11. Several details of paint degradation. On top, the orange red lead is darkened (f. 144); on the bottom, the vermilion is also darkened (f. 8).

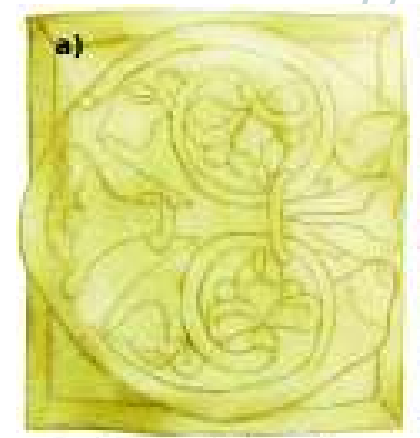

drawing + chalk + glue

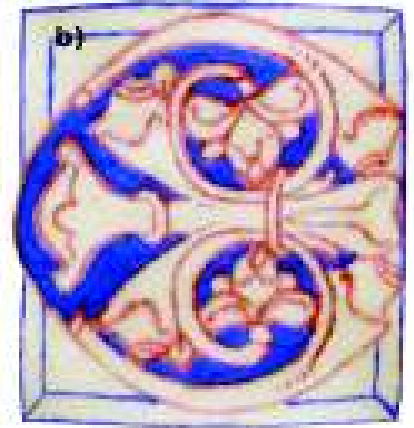

drawing + chalk + glue + paints

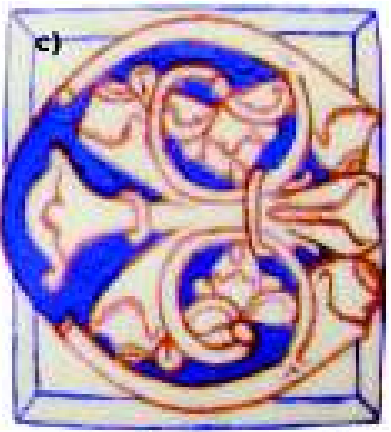

paints without preparation

Figure 12. Step-by-step on the construction of the illumination from f. 8 from Alcobaça Beatus: (a) a coat of parchment glue is applied on top; (b) the blue paint made of parchment glue is applied on the background of the initial and then the outlines in lac dye are made; (c) the blue and lac dye paints are applied without any preparation layer.

In the case of some of the unfinished initials of the Alcobaça Beatus where the backgrounds were not painted, a yellowish coat exceeding the edges of the initials was noted. This layer was identified as a mixture of a protein binder and chalk (Figure 17).

The Liber diversarum arcium (c. 1400) contains a recipe on how to prepare parchment before painting: 

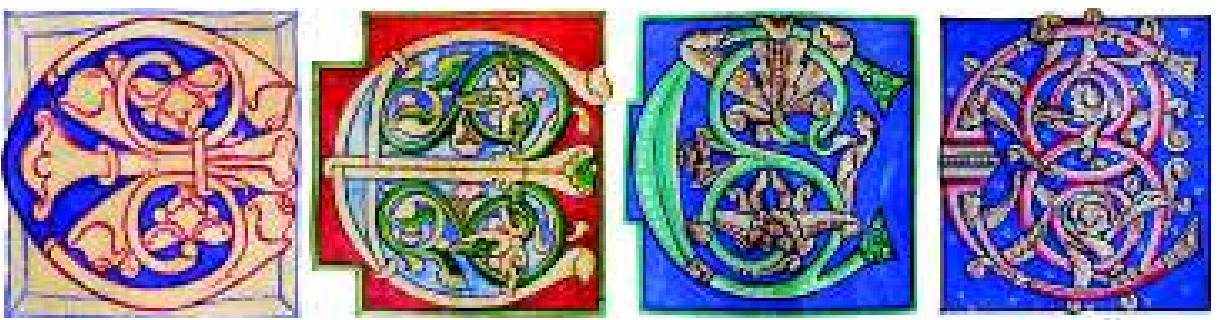

Figure 13. Unfinished initial from ALC 247, f. 8; followed by several finished initials from other Alcobaça manuscripts: ALC 249, f. 36v; ALC 419, f. 133; ALC 421, f. 232.
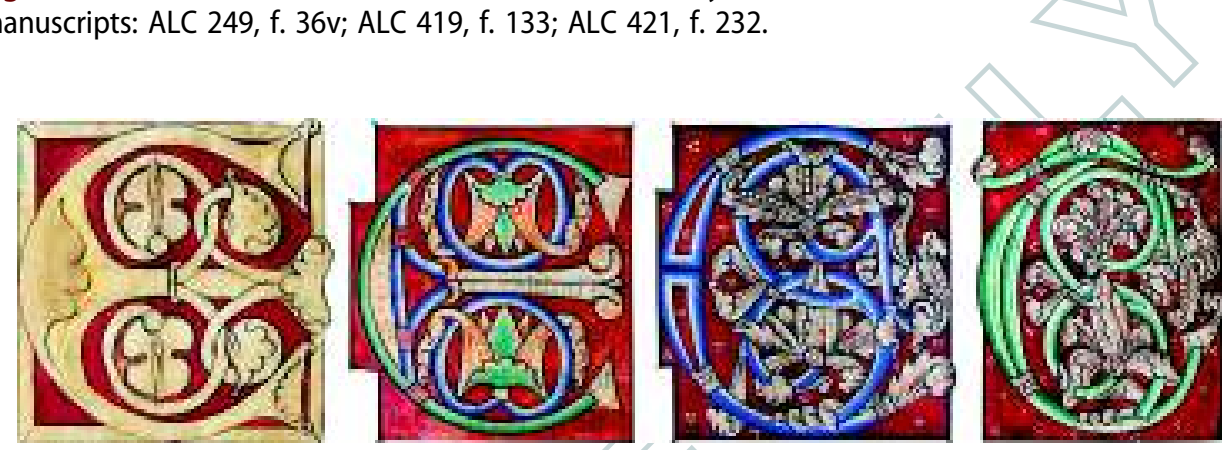

Figure 14. Unfinished initial from ALC 247, f. 15v; followed by several finished initials from other Alcobaça manuscripts: ALC 419, f. 28v; ALC 421, f. 81v; ALC 421, f. 234v.
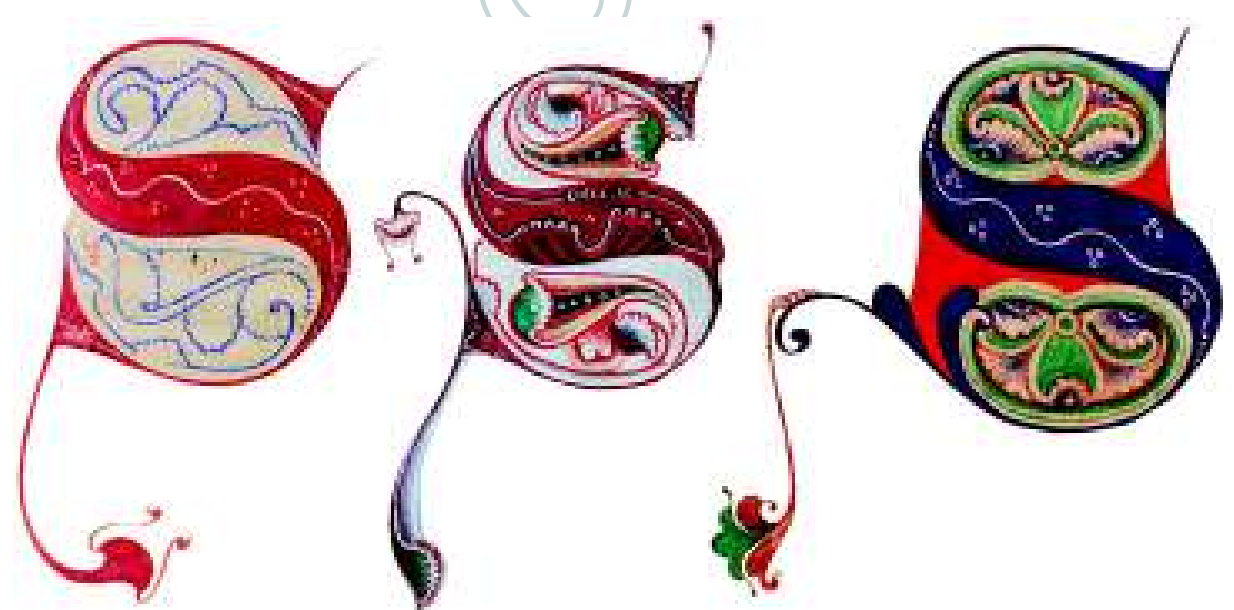

Figure 15. Unfinished initial from ALC 247, f. 19v; followed by several finished initials from Alc 402, f. $15 \mathrm{v}$ and Lv 15, f. 4 (both produced in Alcobaça scriptoria, for more details please see text).

On the place in which one wants to apply colour, the previous day, or the same, apply some gum-arabic-water or parchment glue, because, as you know, sometimes moisture or the nature of parchment alters colours. ${ }^{47}$

${ }^{47}$ Montpellier, Bibliothèque interuniversitaire, Manuscript H 277, f. 84r. See Clarke, The Montpellier Liber diversarum arcium, 104. 


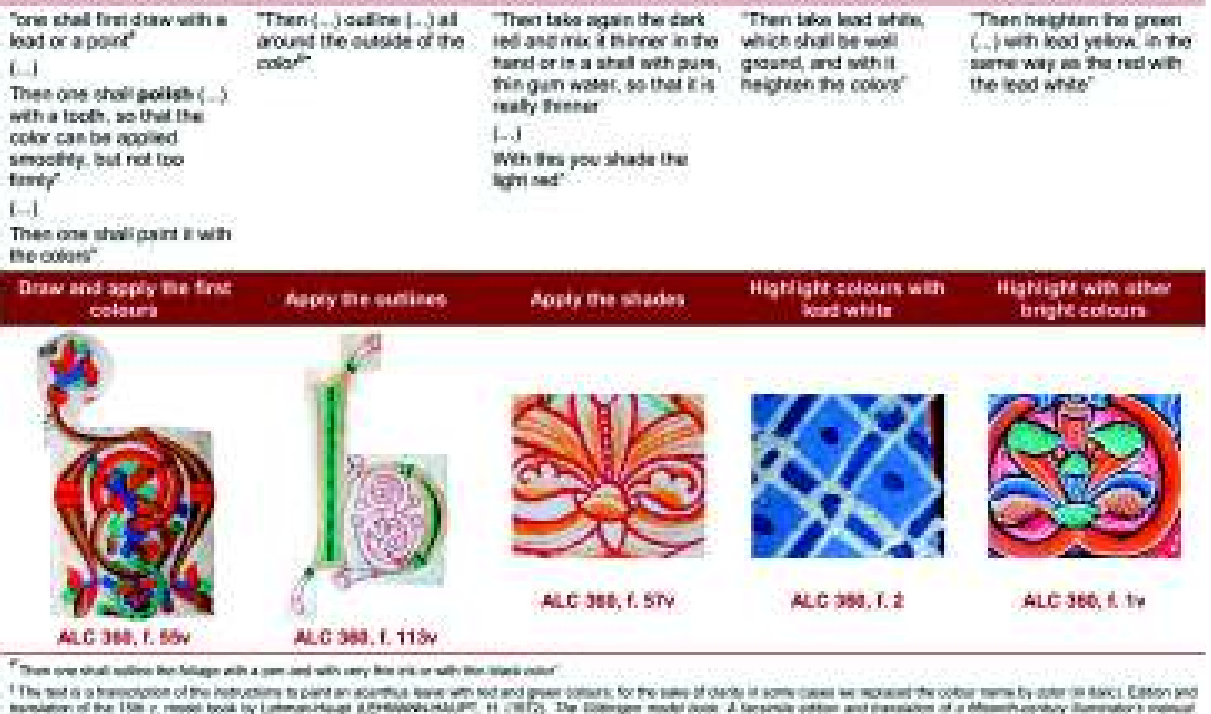

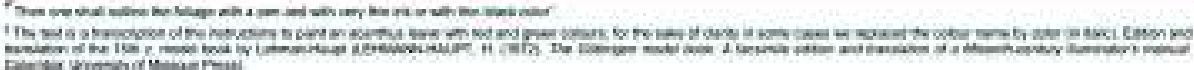

Figure 16. Comparison of unfinished initials in ALC 360 with the instructions on how to illuminate an acanthus leaf in rose colour with a green reverse.
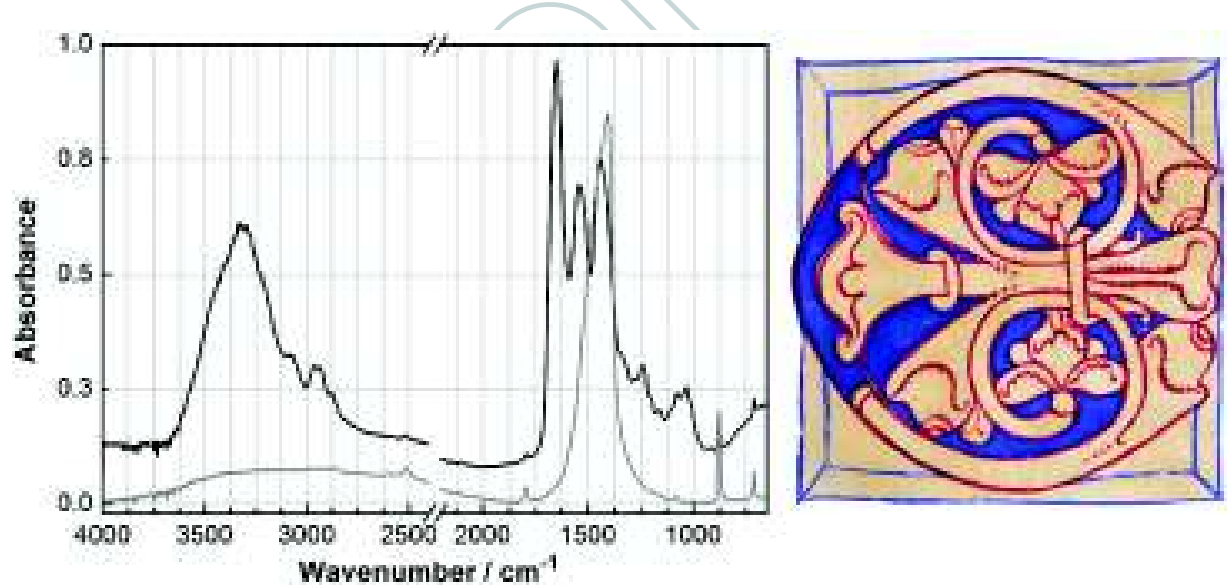

Figure 17. Infrared spectrum of the yellowish preparation layer found in the background of the initial on folio 8 with a calcium carbonate reference in grey. On the right, the unfinished initial from f. 8 .

The chalk may have been introduced when the surface of the parchment was being prepared and remained on the surface owing to its particle size, or it may have been applied with the glue. ${ }^{48}$ We were able to reproduce this technique by illuminating an initial of our own from f. 8, first applying a layer of chalk with a brush onto a sheet of fresh parchment, then a layer of parchment glue, and finally the coloured paints. The same initial was reproduced immediately to the right but without applying the preparation layer. The differences between the colours of the two initials were subtle. The initial with

${ }^{48}$ We thank Mark Clarke for pointing this out and for his very helpful suggestions. 
the preparation layer was less luminous but had higher levels of yellow, whereas the bluish tones were enhanced, though only slightly. ${ }^{49}$ Thus, it is possible that this preparation of the parchment was undertaken to increase the stability and durability of the paint.

\section{Colour mapping of the Alcobaça Beatus}

As well as an analysis of the molecular characterisation of pigments, we developed a new tool, "colour mapping", to gain further insight into the meaning of colours in the context of Portuguese Romanesque manuscripts. ${ }^{50}$ Through colour mapping, which involves the systematic quantification of the main colours present in a codex, we identified a unique colour palette for each of the scriptoria based on three dominant colours: red, green and blue. Analysing the distribution of colours allowed us to highlight distinctive tendencies, such as a preference for green at Alcobaça and red at Santa Cruz. Moreover, the relative distribution of the applied colours suggests that the older monasteries of Lorvão and Santa Cruz, where red predominates, used a colour palette typical of ninthto eleventh-century Iberian manuscripts, as well as a newer colour palette indicative of French influence, which was characterised by the increasing use of blue as a replacement for green.

Colour mapping of the Alcobaça Beatus revealed the predominant use of red, amounting to $58 \%$ of the colours found in the manuscript: the colours used include $33 \%$ vermilion and $25 \%$ lac dye (Figure 18). The second most prevalent colour was green, at $22 \%$, followed by $11 \%$ lapis lazuli blue, $4 \%$ pink/salmon colour, $3 \%$ lead white and $2 \%$ red lead.

This distribution diverges greatly from the standard Alcobaça colour palette (Figure 18). Such a high proportion of red in a manuscript has been observed only in examples from Santa Cruz de Coimbra. As was the case for the Lorvão Beatus, the colours applied in the Alcobaça Beatus were chosen to serve this specific text. The predominance of vermilion may be ascribed to a desire to maintain an Iberian tradition or to underscore the message of the text using the colour of light red. ${ }^{51}$ By comparing this palette with that of the Lorvão Beatus, ${ }^{52}$ it is possible to conclude that the colour system of the Alcobaça codex is more modern, on the basis of the presence of green and blue.

\section{The bookbinding}

A set of bookbindings found in the twelfth- and thirteenth-century manuscripts from the scriptorium of Alcobaça are exceptional pieces in the context of medieval bookbinding owing to their lack of alterations, especially given how often alterations were made to medieval bookbindings over the centuries. The pioneering study of the Alcobaça bindings by Aires Nascimento and António Dias Diogo shed some much-needed light on this frequently neglected aspect of the medieval codex. ${ }^{53}$ Primitive bookbindings from Alcobaça can be divided according to two main typologies. In the first type, wooden boards are

\footnotetext{
${ }^{49}$ With preparation: $L^{*} 33.4 \pm 2.3 ; a^{*} 4.7 \pm 0.6 ; b^{*}-31.9 \pm 1.6$; without preparation: $L^{*} 36.7 \pm 0.8 ; a^{*} 4.1 \pm 0.6 ; b^{*}-31.3 \pm 1.1$.

${ }^{50}$ Melo, Castro and Miranda, "Colour: between Beauty and Meaning", 182-5. A total of thirty-five manuscripts were analysed with the mapping tool: thirteen from Santa Maria de Alcobaça, nine from São Mamede de Lorvão, and thirteen from Santa Cruz de Coimbra.

AQ3 ${ }^{51}$ Gage, "Color and Culture", 58

${ }^{52} 49 \%$ orpiment, $36 \%$ red lead, $11 \%$ vermilion, $3 \%$ black, $1 \%$ brown

${ }^{53}$ Nascimento and Dias Diogo, A encadernação Portuguesa medieval.
} 

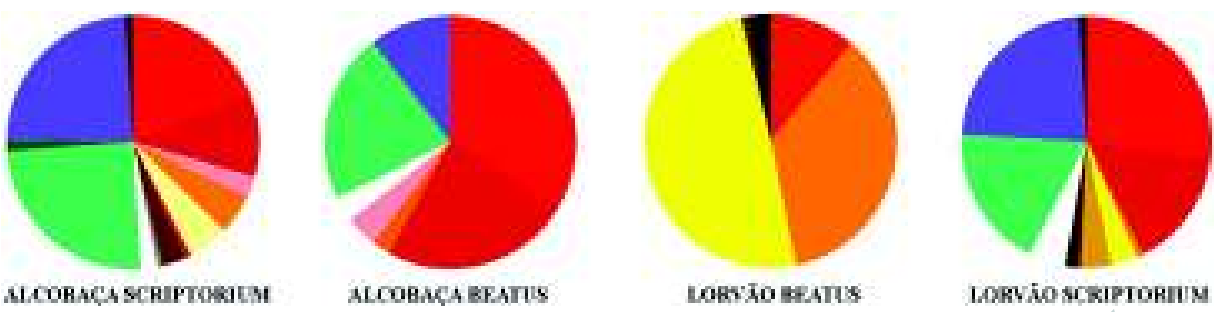

Figure 18. Colour mapping of the Alcobaça and Lorvão scriptoria and their Beatus manuscripts.

covered with a parchment skin as a lining and then by a heavy leather cover, possibly an alum-tawed skin, ${ }^{54}$ forming an envelope binding (e.g. MS Alc. 244, 416, 426); the second type also uses parchment as lining material and a traditional brown leather as the covering material, which was possibly vegetable-tanned, and did not have the envelope flap (e.g. MS Alc. 333, 341, 401). These bindings, with two skins as lining and covering materials, emphasise the sophisticated method which would have been necessary to apply them: intricate needlework was used on mitred corner turn-ins. The stitching is on the verso and requires the use of a loose thread then pulled to slide on the skins, which are finally fixed by delicate wooden pins. As expected for this period, leather tooling work is absent from most of these bindings; the decoration consists of a fine stitching and the contrast provided by the different colours of skins, as well as metal elements, used.

The representative features of Alcobaça's early bookmaking include the continuous sewing of the quires onto split thongs that form raised bands, as well as the lacing technique (using this technique the thongs were channelled through tunnels chiselled into the heavy wooden boards and then fixed in place); the shape and size of the boards, which are slightly rounded only on the front cover, which are the exact size of the textblock; the heavy headbands; the straight spine that allows for the easy opening of the book; and the strong, protective metal bosses. ${ }^{55}$

The binding of the codex exhibits signs of restoration from the twentieth century, probably undertaken in the late seventies, as confirmed by the library staff. These interventions included new wooden boards and parchment skin.

The original parchment skin is still present on top of the new one that was inserted during the restoration process (Figures 19 and 20). Although the heavy alum-tawed skin seen on most Alcobaça bindings is missing, traces of a lost covering of this type were found attached to the headband and the back board. Remains of alum-tawed leather were also found on the headband stitches. Moreover, the headbands on tab endbands are finished in a distinctly semi-circular shape. This original element from the Beatus binding is a typical feature of bookbindings from this period, including those in the Alcobaça scriptorium. ${ }^{56}$ The three slit thongs, linked through continuous sewing to the heavy headbands, also appear to be original, although a long strip of new skin was

\footnotetext{
${ }^{54}$ The process in antiquity produced a white skin, which was prepared in an aqueous solution of a double salt of aluminium and potassium sulphates as opposed to the brown skins or tanning leathers, produced with tanning agents, always from vegetable sources, before the nineteenth century.

${ }^{55}$ Nascimento and Dias Diogo, $A$ encadernação Portuguesa medieval, 35-40.

${ }^{56}$ This type of extended tab leather lining on the headband was a typical feature of Carolingian and Romanesque bindings. It was discontinued in the Gothic period. See Szirmai, The Archaeology of Medieval Bookbinding, 121-7, 159-62, 203-7. For examples from Alcobaça, see Nascimento and Dias Diogo, A encadernação Portuguesa medieval, 34-5.
} 

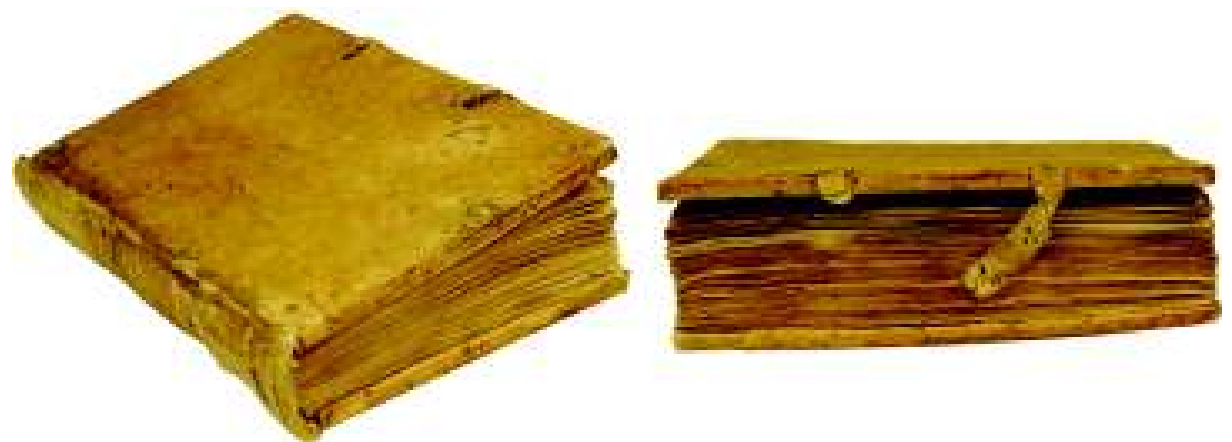

Figure 19. Alcobaça Beatus binding. Left: the non-original front parchment covering. Upper right: the side textblock perspective showing some parts of the original white alum-tawed skin straps.
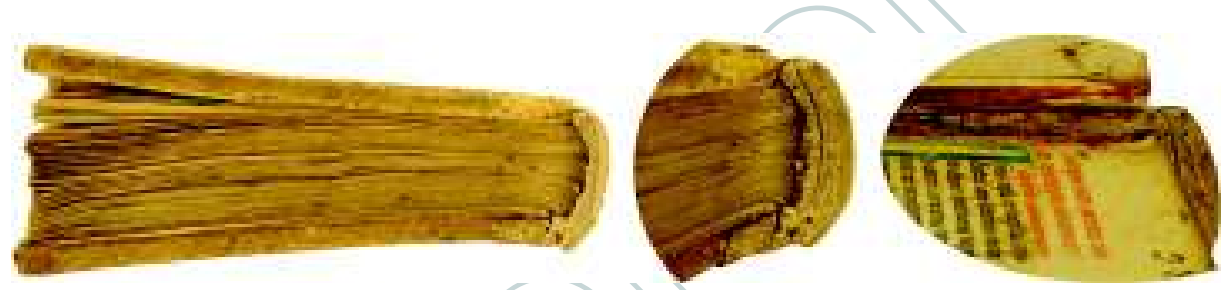

Figure 20. Details of the original binding of the Alcobaça Beatus. Left: side textblock perspective with original elements on the headband. Centre: detail of the original headband with straight sewing. Bottom right: detail from the original alum-tawed leather tab used on the headband.

glued along the spine in order to attach the textblock to the new boards. Some folios have been slightly trimmed, most likely after the substitution of the wooden boards.

The now-missing clasps were held in place by the original straps, which are made of finely stitched double alum-tawed skin; however, we believe that the copper pins used to hold them were added later, when the boards were replaced. The straps have traces of the same chemical elements found in the small piece of leather attached to the tail side of the spine; bromine in particular, which was not found in the parchment covering, should be noted. This indicates that these parts of the original binding were most likely made from the same material. New pastedowns of tinted parchment were applied and endleaves, of paper for the front board and of parchment for the back board, were pasted on top during the twentieth-century restoration.

Five marks on each side of the parchment front board cover indicate the previous presence of metal bosses; microXRF revealed that these bosses were made of brass. ${ }^{57}$ In contrast, on the back board a corrosion stain on the parchment cover, probably from the missing central boss, indicates the former presence of a furnishing made of iron, as determined via microXRF.

${ }^{57}$ We compared these data with a thirteenth-century manuscript from Alcobaça (MS Alc. 338), which is believed to have its original binding, according to Nascimento and Dias Diogo (ibid., 50-1). Using microXRF, we determined that the thirteenth-century bosses still present in this binding were made of brass. More systematic work on these bindings is necessary to reach additional conclusions. 
Despite the modern restoration of the binding of the Alcobaça Beatus, these remaining traces of its original state suggest that it was produced in the Alcobaça scriptorium. The evidence found at the tail of the spine and the headband is consistent with what we know of the style of bookbinding employed at Alcobaça during the twelfth and thirteenth centuries, thus reinforcing the argument that the manuscript was in fact produced there, an argument which is also based on other evidence, including the colourants and the style.

\section{Discussion}

The use of technical and art historical methods to gather data on several aspects of the manuscript's production gave rise to new empirical information, which in turn allowed us to corroborate the traditional hypothesis that this Beatus Commentary was produced at the scriptorium of Alcobaça. This conclusion is significant because it means that this is the first Beatus manuscript that can be definitely linked to a Cistercian scriptorium. Furthermore, we have also determined that the Alcobaça and Lorvão Beatus manuscripts exhibit three main divergences: the arrangement of the texts, the type of decoration one is fully illustrated with an iconographic programme and the other has decorated initials - and the materials used.

The overall analyses of these results prompt several questions. Should we consider that the Alcobaça Beatus was not copied from the Lorvão Beatus? Why did the copyist alter the order of the preface texts and duplicate the prologues of the Alcobaça Beatus? Could the absence of illustrations be a result of the Cistercian prohibition of images, despite the fact that other Cistercian monasteries were producing richly decorated manuscripts at this time? Why did this scriptorium copy an Iberian Commentary on the Apocalypse if Cistercians in general did not show a great interest in the Book of Revelation? Should we consider this to be a factor of Cistercian regional identity?

\section{The Alcobaça and Lorvão Beatus manuscripts}

Although the apparently random sequencing of the texts in the Alcobaça Beatus could be due to scribal error, other reasons might also explain this anomaly, such as the copying of a model that already had such an arrangement. Thus, one must ask whether the Lorvão manuscript actually served as the model for the manuscript under study. It cannot be denied that the Lorvão Beatus and Alcobaça Beatus have much in common. A number of identical marginal glosses are found in both these manuscripts, but these glosses are unique among Beatus manuscripts. ${ }^{58}$ In addition, the two Antichrist Tables, which are practically identical in terms of arrangement, text and motifs, are also unique within the Beatus tradition.

Nevertheless, there is some evidence for the possible independence of Alcobaça from Lorvão. It is important to bear in mind that the Lorvão text frequently uses abbreviations, a feature not shared by the Alcobaça Beatus. Although these abbreviations were highly standardised and therefore would have been familiar to a professional scribe, they nevertheless would have increased the likelihood of transcription errors. The relative lack of

\footnotetext{
${ }^{58}$ Klein, Apocalipsis de Lorvão, 43, n. 25.
} 
such errors in the Alcobaça Beatus may indicate that it was not copied from a model with a proliferation of abbreviations.

Much more important to this discussion is the existence of the gloss describing an image depicting the Message to the Church of Thyatira; this image is situated within the text in Lorvão but in the margin in Alcobaça. The image itself is present in Lorvão but not in the unillustrated Alcobaça copy. Plus, in relation to the respective positioning of chrismons in each manuscript, which are placed opposite the phrases hoc monograma and hunc caracterem, in the Alcobaça manuscript they appear between the text columns (f. $142 \mathrm{v}$ ) or in the margin (f. 145r), whereas in the Lorvão codex (ff. 165v and 168) they are embedded within the text. If the Lorvão codex was the model for the Alcobaça manuscript, we think that the copyist would have placed both the chrismons and the gloss within the text. In addition, why should the scribe add this gloss, especially in the margin, if no image was expected? We should point out here that in Lorvão, the portion of the text block in which it appears was later outlined in red and labelled with the word glosa (gloss). This suggests that we should at least consider the idea that the Alcobaça manuscript was not copied from the Lorvão copy but confronted to it later at some point - and at this time, the text block in Lorvão was outlined as a gloss and copied into the margin of the Alcobaça manuscript.

The Alcobaça Beatus itself preserves a late medieval note on its final folio stating that it was lent by the monk Nicholao of Alcobaça to the monk Joham of "San Mamede", which may mean that there is a link between both manuscripts and this also lends support to the theory that the Alcobaça Beatus was confronted to the Lorvão copy at some point after being produced:

This book belongs to the monastery of Alcobaça. It was lent by the monk Nicholao to Joham of St Mammas, who promised to return it to the monastery of Alcobaça before his death. And this book cannot be sold or destroyed. (f. 183r, col. 2)

This loan is not surprising since there is evidence that these two Portuguese monasteries exchanged manuscripts: for instance, the Passio et Miracula Sancti Thomae Cantuariensis was produced in the scriptorium of Lorvão and later loaned to Alcobaça. ${ }^{60}$ However, there are several issues to examine. First, it has been traditionally considered that this "San Mamede" refers to St Mammas of Lorvão, but it could refer to another monastery dedicated to St Mammas. Secondly, the note can be dated on palaeographic grounds to the last decades of the fifteenth century. If the loan took place between Alcobaça and Lorvão, was it in the fifteenth century, or does the note refer to a loan made previously, for instance at the turn of the thirteenth century?

Thirdly, regarding the two monks in the note, who are they? The mention of Joham from São Mamede might at first come as something of a surprise since the male community living at Lorvão left the house at the turn of the thirteenth century, when it was converted to a female community. Nevertheless, it is possible that this Joham could have been a confessor, as Cistercian nunneries had male confessors. The second monk mentioned in the note, Frei Nicholao of Alcobaça, could be Abbot Nicolau Vieira, who was responsible

\footnotetext{
59"Este liuro hes do moesteyro d'Alcobaça ho qual dom frey Nicholaao emprestou a frey Joham di san Mamede, ho quall frey Johan se obrigou ao tornar ao dito moesteiro d'Alcobaça ante de sua morte e este liuro non pode ser uendidu nin struydo."

${ }^{60}$ Lisbon, Biblioteca Nacional de Portugal, Ms. Alc. 143. See Nascimento, "Tempos e livros medievos", 402.
} 
for endowing the monastery with commendatory abbots in 1475, which was frowned upon by the Portuguese monarchy. ${ }^{61}$ However, he was not remembered fondly, and was in fact condemned to a damnatio memoriae by the monks. ${ }^{62}$

As is clear from the discussion thus far, several factors have led us to consider the Alcobaça Beatus to be a copy of the Lorvão, whereas other factors point to the independence of the Alcobaça copy and the existence of now unknown Beatus exemplars in Portugal at this time. Only further investigations that bring new evidence to the fore will shift the balance in favour of one or other possibility. In this regard, the tracking of documental sources and monastic funds could provide information in the future.

\section{Cistercians, the Book of Revelation and the Beatus Commentary}

The late twelfth and early thirteenth centuries witnessed a revival in the production of Beatus manuscripts in the Iberian Peninsula - a phenomenon which some scholars relate to the many newly founded monasteries in Iberia, both Cistercian and Benedictine, and to the traditional use of the Beatus manuscripts in monastic reading practices. ${ }^{63}$

Two of these thirteenth-century copies belonged to the Cistercian monasteries of San Andrés de Arroyo (Palencia) ${ }^{64}$ and Santa María la Real de Las Huelgas (Burgos), although it is not certain where they were produced. ${ }^{65}$ Another copy, the Poblet Beatus, which is the 1055 only unillustrated Beatus contemporary to the Alcobaça manuscript, has been linked to the scriptorium of the Catalan monastery of Santa Maria de Poblet and dated to the second half of the twelfth century. ${ }^{66}$

Besides producing, commissioning and purchasing new copies, Cistercian monasteries of the Iberian Peninsula also acquired older Beatus manuscripts. The Burgo de Osma Beatus, for instance, was copied in 1086 at the monastery of Sahagún (Sts Facundus and Primitivus, León), but later came to be linked to Santa María de Carracedo (León), as evidenced by the fact that it preserves two early thirteenth-century bulls pertaining to this monastic centre, which adopted Cistercian rule in $1203 .{ }^{67}$ Similarly, the Lorvão Beatus, produced in 1189 when the Portuguese monastery was still inhabited by a male community, was retained in the monastic library after it was transformed into a Cistercian nunnery a few decades later. ${ }^{68}$ Finally, today there are two Beatus fragments in the Archivo Provincial de Zamora which have Visigothic writing and date to the first half of the tenth century; these may come from San Martín de Castañeda (Zamora), ${ }^{69}$ a monastery that adopted Cistercian rule in $1245 .^{70}$ In addition, bringing together data from both medieval

${ }^{61}$ Saúl Gomes notes that the monastery of Alcobaça was an early case of the complex system of commendatory abbots. See Gomes, Visitações a Mosteiros, 21 and 28-30.

${ }^{62}$ On Abbot Nicolau's complicated relationship with the community, see the later chronicle written by a monk of Alcobaça:

São Boaventura, Historia chronologica, 85.
AQ4 ${ }^{63}$ Klein, "The Apocalypse in Medieval Art", 187; Klein, "La fonction", 318; Klein, "Im Spannungsfeld von Endzeitängsten", 42 (we have learned to know this article through the author, whom we thank); Walker, Views of Transition, 88-90.

${ }^{64}$ Paris, Bibliothèque Nationale de France, ms. nouv. acq. lat. 2290. The first record of this manuscript is found in the codex itself: a note from the fourteenth or fifteenth century indicates that it belonged to the convent of San Andrés de Arroyo. Previously, it was believed that the manuscript was donated to the monastery by King Fernando III, and was not copied in the monastery itself. See Vivancos, "El Beato de San Andrés", 65.

${ }^{65} \mathrm{New}$ York, Pierpont Morgan Library, ms. 429. See Voelke et al., Estudio del Manuscrito.

${ }^{66}$ Suárez González, Fragmentos de libros, 52.

${ }^{67}$ Burgo de Osma, Catedral, Cod. 1.

${ }^{68}$ Marques, "O mosteiro de Lorvão", 57-74.

${ }^{69}$ Zamora, Archivo Histórico Provincial, Fragmentos 276-7. Suárez González, "El Beato", 434-77.

${ }^{70}$ Vega Casado, "El monasterio de San Martín", 479-99. 
and modern sources, it seems that beyond the Beatus Commentary, other exegetes on the Apocalypse experienced some popularity within Cistercian houses, for instance the Expositio by Berengaudus. ${ }^{71}$ The library of Alcobaça itself owned a twelfth-century copy (MS Alc. 232), and the presence of a copy of this work in the Iberian Cistercian monasteries of Sandoval and Carracedo was recorded by the sixteenth-century Spanish historian Ambrosio de Morales. $^{72}$

It seems clear, therefore, that the Beatus Commentary and the Book of Revelation itself were valued by Cistercian monasteries across northern Iberia; the question remains, however, as to whether it is exclusively an Iberian phenomenon. The Cistercians are 1090 known to have spurred the production of certain types of texts, such as the martyrology and the Song of Songs. ${ }^{73}$ In general, the apocalyptic text was not as central to the Cistercian mindset as it was to the Benedictines. However, it is also true that the order did not leave eschatological matters aside completely. Inventories of Cistercian monasteries register commentaries on the Apocalypse by other authors, such as a copy of the Expositio in 1095 Apocalypsim by Haymon d'Auxerre, in the monastery of Preuilly in 1210, which later became part of the library of the Abbey of Vauluisant, ${ }^{74}$ or glossed Apocalypses, as is the case in an entry in the inventory of the monastery of Clairvaux that was drawn up by Abbot Pierre de Virey in $1472 .{ }^{75}$ Cistercian scriptoria even illustrated commentaries on the Apocalypse, as demonstrated by the historiated initials of the Commentary on the Apocalypse of Rupert of Deutz in a manuscript produced at the scriptorium of the Cistercian monastery of Heiligenkreuz near Vienna, which dates to the third quarter of the twelfth century. ${ }^{76}$

In addition, two prominent Cistercian monks reflected and commented on the Apocalypse. One of them was the Calabrian Joachim of Fiore (1132-1202), whose commentary on the Book of Revelation was included by Innocent III in his 1199 index of obscure books of the Bible, which listed texts that should not be translated into Romance languages or indeed be commented upon. The other monk was Geoffrey of Auxerre, who was a student of Peter Abelard, later a secretary of Saint Bernard and also a prominent figure within the Cistercian order during the twelfth century. He wrote a series of sermons on the Book of Revelation for several liturgical occasions, which he later collected and reworked as a compilation. ${ }^{77}$ Moreover, he was abbot of several Cistercian abbeys in different territories, including Fossanova and Hautecombe. This is especially significant in light of the recent proposal by Arnauld Delerce that the Geneva Beatus could have been preserved at the library of one of these two houses. This copy, which is part of a 1115 manuscript that also contains a copy of Priscilian's Institutiones Grammaticae, was produced in southern Italy in the eleventh century but contains a note indicating that it belonged to the library of the Cistercian house of Aulps (Haute-Savoie, French Alps), where according to Delerce it arrived through connections with the Cistercian abbeys of Fossanova and Hautecombe. ${ }^{78}$

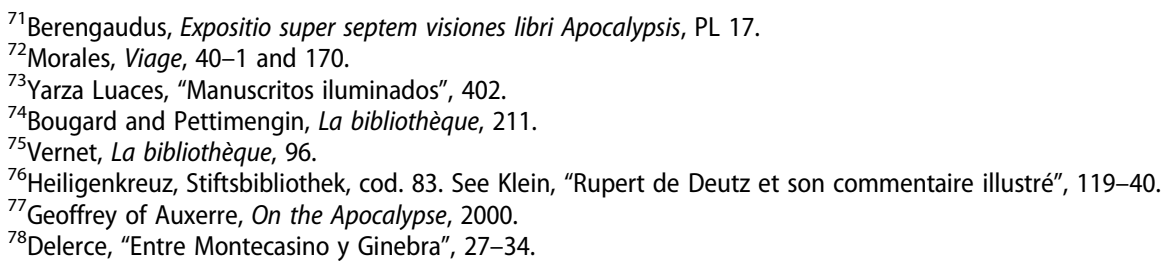


Thus even if the Book of Revelation was not a central point in Cistercian thought, it still played a more significant role than has previously been recognised. Regarding the Beatus Commentary, recent studies provide evidence that there were copies in Cistercian houses beyond the Pyrenees, which means we should understand this work not only in the 1130 context of an Iberian tradition but within a broader European context. Finally, the abbey of Alcobaça itself had at least two commentaries on the Apocalypse, one by Beatus and another by Berengaudus, which indicates the interest of the community in the Book of Revelation overall.

The Alcobaça Beatus provides further material to consider within this context. 1135 Two notes that were added at the end of the manuscript at a later date (f. 183r, col. 2) refer to the precept to be applied to all those monks who arrived late to the Divine Office:

A certain monk who is late to the Hours and often fails to sit in his chair, is warned, and whether not fully awake or fully asleep, is given a note and ordered to read it. The note reads: "The man who deprives himself of the Divine Office deprives himself of grace in the present and of glory in the future."79

Another note was added to the inside of the back cover of the codex; it is very abraded and largely illegible, but includes a date that is still visible: Era M IIIIc XXVIIe - that is, AD 1389. On the basis of these few legible words, it can be inferred that the manuscript had been seen (Este liuro vyó) by the abbot and a bachiller. It thus appears that the manuscript was being consulted and even used for the Divine Office, at least during the fourteenth and fifteenth centuries, but presumably also before and after. Through these notes, the Alcobaça Beatus - along with the Lorvão Beatus, which contains two glosses indicating that the manuscript was read in the refectory, ${ }^{80}$ and the Las Huelgas Beatus, ${ }^{81}$ in which a framed marginal note reads "lege et mira" (read and see/admire, f. 83), along with two prayers linked to the Liber Usuum in its colophon (f. 184) $)^{82}$ - contributes evidence of how Cistercian communities actually used this work within the context of prayer and contemplation. ${ }^{83}$

\footnotetext{
${ }^{79}$ The first note may be dated to the fifteenth century and reads as follows: "Cuidam religioso tarde uenienti ad horas et se subtrahenti et [fer] frequenter sedenti in sella dum pulsaretur et nec plene uigilanti nec plene dormienti delata est scedula et preceptum est ut legeret in qua legit ita: homo qui subtrahit se a diuino seruicio subtrahit sibi in presenti gratiam et in futuro gloriam." The second appears immediately below; it can be dated to c. 1350 but seems to imitate twelfth/thirteenth century script (and substitutes cella for sella): "Quidam religioso tarde uenienti ad horas et se subtrahenti et frequenter sedenti in cella dum pulsaretur et nec plene uigilanti nec plene dormienti delata est scedula et preceptum est ut legeret in qua legit ita: homo qui subtrahit se a diuino seruitio subtrahit sibi in presenti gratiam et in futuro gloriam." (A certain monk who is late to the Hours and often fails to sit in his chair, is warned, and whether not fully awake or fully asleep, is given a note and ordered to read it. The note reads: "The man who deprives himself of the Divine Office deprives himself of grace in the present and of glory in the future)".

${ }^{80}$ These notes date to the end of the fifteenth or beginning of the sixteenth century. The first is located between the two text columns of folio 12, at the beginning of Book I, and the second is at the end of the Storia of Apocalypse I, 10-20, on folio 17; it appears immediately below the text of the right column and just above the depiction of Hell. See Klein, Beato de Liébana, 147; Williams, The Illustrated Beatus, vol. 5, 32.

${ }^{81}$ Williams, The Illustrated Beatus, vol. 5, 39-40.

${ }^{82}$ Raizman, "Prayer, Patronage, and Piety", 236-73. On the Liber Usuum see Lackner, "The Liturgy of Early Citeaux", 18-19; Lekai, The Cistercians, 248-61.

${ }^{83}$ The use of Beatus manuscripts by communities of other orders has also been verified. In a recent article, José Antonio Fernández Flórez has studied the marginal notes of those Beatus manuscripts belonging to Branch lla, and verified the existence of several notes, common to all these copies, that evidence theological-dogmatic content. See Fernández Flórez, "Beato y los Beatos", 264-9. The Saint-Sever Beatus also includes several liturgical pieces recently studied by Klein, "Le Beatus de Saint-Sever", 15-16 (we have learned to know this article through the author, whom we thank).
} 


\section{An altered and unillustrated Beatus at the Cistercian abbey of Alcobaça}

Some decades ago, several scholars suggested that the success of the Beatus Commentary in the later twelfth and thirteenth centuries could be related to sumptuousness and prestige in the monastic communities. ${ }^{84}$ The ownership of luxurious, beautifully decorated manuscripts may have served to ennoble monastic institutions. The early precepts of the Cistercian order concerning poverty and strict simplicity would seem to preclude the production or ownership of illuminated manuscripts. Yet, within the Beatus tradition and from this time, there are the unillustrated copies from Alcobaça and Poblet, both of which are traditionally believed to have been produced at Cistercian scriptoria. We believe that a comparative study of both manuscripts, including how they were used, can best be undertaken through a multidisciplinary examination of the Poblet Beatus using methods from both the natural and human sciences - an examination such as the one undertaken here for Alcobaça. Until this happens, however, only the Portuguese manuscript can be used to address the issues involved in producing an unillustrated Beatus by and for a Cistercian community.

The Alcobaça Beatus and its creation at the scriptorium of Alcobaça should be examined in connection with the community's specific interests. This manuscript was produced without illuminations on purpose. Why would this be the case? Contrary to other Iberian Cistercian monasteries that acquired fully illustrated codices, in around 1200 the scriptorium at Alcobaça seems to have been more faithful to the early Cistercian precepts against the usage of images and luxurious decoration. ${ }^{85}$ In the manuscripts produced at the scriptorium in the late twelfth and early thirteenth centuries, we may note the use of colour, floral elements and even figural decoration in some cases: for instance, the Etymologies contains a depiction of the Arbor Consanguinitatis (MS Alc. 446, f. 95v), ${ }^{86}$ or the De Avibus by Hugh of Fouilloy (MS Alc. 238) ${ }^{87}$ However, the scriptorium mainly produced unillustrated manuscripts, choosing instead to decorate them exclusively with initials, which was in strict accordance with Cistercian asceticism and the prohibition against the use of images by the monks.

\section{Final thoughts}

By combining various areas of expertise in this research, we were able to (re)discover the Alcobaça Beatus. Our analysis of the manuscript, which used combined methods from the natural sciences and the humanities, supports the hypothesis that this copy was made by and for the Cistercian community which inhabited the Portuguese monastery of Alcobaça around 1200. Furthermore, we know now that this copy, besides being unillustrated, was also altered in terms of textual sequence, yet the evidence still suggests that the monks used it for the Divine Office. The fact that the community also owned another commentary on the Apocalypse, by Berengaudus, leads us to believe that the Cistercian house had an interest in the Book of Revelation itself which went beyond the Beatus Commentary.

The Alcobaça Beatus - in the present article - and the previously studied Lorvão Beatus have been analysed in depth using a multidisciplinary approach. This constitutes the basis

\footnotetext{
${ }^{84}$ Cahn, "The Rule and the Book", 139-72; Yarza Luaces, "Manuscritos iluminados", 399.

${ }^{85}$ Waddell, Twelfth-Century Statutes, 516.

${ }^{86}$ Miranda, "A construção de uma imagem de poder", 341-54.

${ }^{87}$ Castro, "The Secrets behind the Colour", 31-55.
} 
for examining other Beatus manuscripts, such as the Poblet Beatus, which could result in the evolution of the discussion on the Beatus Commentary, Cistercian manuscripts and indeed on colour construction in the Middle Ages.

Finally, our study of the Alcobaça Beatus prompted several questions that could not be answered within this paper owing to constraints of space but constitute fascinating avenues of investigation for future research. Did the renunciation of images and the alteration of the textual sequence alter the use and understanding of the work? How should we understand the diagrammatic structures - the Tables of the Antichrist - which were maintained even when the iconographic programme was not included? What more can we determine about the role colours played? As a final note: if the issue of colour has been intensively discussed for illuminated Beatus manuscripts, it has yet to be applied to the copies without images.

\section{Acknowledgements}

The authors would like to thank the staff and directory board of the Arquivo Nacional da Torre do Tombo (ANTT) and the Biblioteca Nacional de Portugal (BNP) for their generous support and collaboration. This work has been financially supported by Portuguese funds through FCT - Fundação para a Ciência e a Tecnologia under the CORES PhD programme PD/00253/2012 and project PTDC/EAT-EAT/104930/2008 as well as through the Postdoc grant of Alicia Miguélez Cavero (SFRH/BPD/70305/2010) and the PhD grant of Rita Castro (SFRH/BD/76789/2011). We thank the Associated Laboratory for Sustainable Chemistry - Clean Processes and Technologies LAQV which is financed by FCT/MEC (UID/QUI/50006/2015) and co-financed by the ERDF under the PT2020 Partnership Agreement (POCI-01-0145-FERDER - 007265). Finally, special thanks also go to the scholars who made important contributions to improve this survey, especially Aires Augusto Nascimento, Mark Clarke, Encarnación Martín López, Santiago Domínguez Sánchez, Gregoria Cavero Domínguez, Catarina Barreira and Luís Repâs.

\section{Notes on contributors}

Alicia Miguélez Cavero (amiguelez@fcsh.unl.pt) holds a PhD in History of Art. She is currently a postdoc researcher at the Institute for Medieval Studies of the Nova University in Lisbon, where she is carrying out a project on Beatus manuscripts funded by the Portuguese Foundation for Science and Technology. Her research interests include Gestures in Art, Medieval Iconography and the use of Medieval Images in Modern Times.

Maria João Melo (mjm@fct.unl.pt) is Associate Professor at the Department of Conservation and Restoration of the Faculty of Sciences and Technology of the Nova University in Lisbon and a research scientist at REQUIMTE (Associated Laboratory for Sustainable Chemistry - Clean Processes and Technologies). Her current research subjects are focused on the study of colour of Portuguese medieval illuminations and the study of the molecules of colour in Art and Nature.

Adelaide Miranda (mmac@fcsh.unl.pt) has been Associated Professor of Medieval Art History at the Department of Art History of the Faculty of Social Sciences and Humanities of the Nova University in Lisbon. Retired from teaching, she is currently a senior researcher at the Institute for Medieval Studies of the Nova University, where she has coordinated several research projects on Portuguese medieval illuminated manuscripts, funded by the Portuguese Foundation for Science and Technology.

Rita Castro (rita.castro@gmail.com) holds an MA in Conservation and Restoration and she is currently finishing a $\mathrm{PhD}$ on the colour and meaning in medieval manuscripts based on the study of 
three medieval copies of the Book of Birds by Hugh of Fouilloy preserved in Portuguese libraries and the Santa Cruz of Coimbra Romanesque collection.

Maria da Conceição Lopes Casanova (mccasanova@museus.ulisboa.pt) holds a PhD in Conservation and Restoration/Theory, History and Techniques. She is currently responsible for the Information and Documentation Centre of the Tropical Research Institute in Lisbon and is invited assistant professor at the Faculty of Sciences and Technology of the Nova University in Lisbon. Works cited

\section{References}

Beati Liebanensis. Tractatus de Apocalipsin, ed. Roger Gryson. Turnhout: Brepols, 2012.

Beato de Liébana. Códice del Monasterio de San Pedro de Cardeña, edición facsímil y comentario. 2 vols. Barcelona: Moleiro, 2001.

Beato de Liébana: la ilustración de los manuscritos de Beato y el códice de Manchester. 2 vols. Valencia: Patrimonio, 2002.

Beato de Saint-Sever. Edición facsímil del códice de la abadía de Saint-Sever, conservado en la Biblioteca Nacional de París bajo la signatura Ms. Lat. 8878. Madrid: Edilán, 1984.

Los Beatos. Europalia 98 España, 26 de septiembre-30 de noviembre 1985, Chapelle Nassau, Bibliothèque royale Albert Ier. Brussels: Europalia, D.L. 1985.

Berengaudus. Expositio super septem visiones libri Apocalypsis, PL 17.

1285 Bondéelle, Anne. “Trésor des moines. Les Chartreux, les Cisterciens et leurs livres." Histoire des bibliothèques françaises 1 (1989): 68-80.

Bougard, François, and Pierre Pettimengin. La bibliothèque de l'abbaye cistercienne de Vauluisant. Histoire et inventaires. Paris: CNRS Éditions, 2013.

Cahn, Walter. "The Rule and the Book: Cistercian Book Illumination in Burgundy and Champagne." In Monasticism and the Arts, ed. Timothy Verdon, 139-72. Syracuse: University Press, 1984.

Castro, Rita. "The Secrets behind the Colour of the Book of Birds". Portuguese Studies on Medieval Illuminated Manuscripts, ed. Maria A. Miranda and Alicia Miguélez Cavero, 31-55. MadridBarcelona: Brepols, 2014.

Clarke, Mark. Mediaeval Painters' Materials and Techniques: The Montpellier Liber Diversarum Arcium. London: Archetype Publications, 2011.

1295 Delerce, Arnauld. "Entre Montecasino y Ginebra: Estudo sobre las vicisitudes del Beato". Beato de Liébana. Códice de Ginebra, 27-34. Burgos: Siloé, 2015.

Díaz y Díaz, Manuel C. Index scriptorum latinorum medii aevi hispanorum. Salamanca: Universidad, 1959.

Díaz y Díaz, Manuel C. “Un nuevo comentario hispano al Apocalipsis.” In Beato de San Millán. Códice 33. Original conservado en la Biblioteca de la Real Academia de la Historia, volumen com-

1300 plementario a la edición facsímil. Madrid: Testimonio, 2005.
Díaz y Díaz, Manuel C. Valerio del Bierzo: su persona, su obra. León: Centro de Estudios e Investigación "San Isidoro", 2006.

Fernández Flórez, José A. “Beato y los Beatos. El Beato de Escalada y su familia.” In San Miguel de Escalada (913-2013), coord. Vicente García Lobo and Gregoria Cavero Domínguez, 239-72. León: Servicio de Publicaciones de la Universidad de León, 2014.

1305 Gage, John. Color and Culture. Practice and Meaning from Antiquity to Abstraction. Berkeley and Los Angeles: University of California Press, 1999. 
Galván Freile, Fernando. "El proceso de internacionalización de la miniatura en torno al año 1200 en la Península Ibérica. El antifonario de Las Huelgas Reales de Burgos." In El monacato en los reinos de León y Castilla (siglos VII-XIII), 437-56. León: Fundación Sánchez-Albornoz, 2007.

Geoffrey of Auxerre. On the Apocalypse, ed. Joseph Gibbons. Kalamazoo: Cistercian Publications, 2000.

1310 Gomes, Saúl António. "Revisitação a um velho tema: a fundação do Mosteiro de Alcobaça." In Actas. Cister. Espaços, Territórios, Paisagens. Colóquio Internacional (16-20 de Junho de 1998, Mosteiro de Alcobaça), vol. 1, 27-72. Lisboa: IPPAR, 2000.

Gomes, Saúl António. Visitações a Mosteiros Cistercienses em Portugal. Sécs. XV e XVI. Lisboa: IPPAR, 1998.

The Göttingen Model Book: A Facsimile Edition and Translations of a Fifteenth-Century Illuminators' Manual, ed. Hellmut Lehmann-Haupt. Columbia: University of Missouri Press, 1978.

Gusmão, Artur Nobre. A Real Abadia de Alcobaça. Estudo histórico-arqueológico. Lisboa: Livros Horizonte, 1992.

Hochuli Dubuis, Paule, and Isabelle Jeger. "Un Beatus découvert à Genève.” Bibliografia dei manoscritti in scrittura beneventana 17 (2009): 11-29.

1320 Inventário dos Códices Alcobacenses. Lisboa: Biblioteca Nacional, 1930-1978.

Klein, Peter. Der ältere Beatus-Kodex Vitr. 14-1 der Biblioteca Nacional zu Madrid. Studien zur Beatus-Illustration und der spanischen Buchmalerei des 10. Jahrhunderts. Studien zur Kunstgeschichte 8. Hildesheim: Georg Olms, 1976.

Klein, Peter. "The Apocalypse in Medieval Art", In The Apocalypse in the Middle Ages, ed. Richard K. Emmerson and Bernard McGinn, 159-99. Ithaca, NY: Cornell University Press, 1992.

1325 Klein, Peter. Beato de Liébana. La Ilustración de los manuscritos de Beato y el Apocalipsis de Lorvão. Valencia: Patrimonio Ediciones, 2004.

Klein, Peter. "Eschatological Expectations and the Revised Beatus". In Church, State, Vellum, and Stone, ed. Therese Martin and Julie A. Harris, 147-71. Leiden: Brill, 2005.

Klein, Peter. "Le Beatus de Saint-Sever. Contexte historique et iconographique." Cahiers de 1330 AQ9 Fanjeaux 51 (forthcoming).

Klein, Peter. "La fonction et la 'popularité' des Beatus, ou Umberto Eco et les risques d'un dilettantisme historique." In Études roussillonnaisses offertes a Pierre Ponsich, 313-25. Perpignan: Le Publicateur, 1987.

Klein, Peter. "Remarques sur le manuscript bénéventin de Beatus récemment découvert à Genève." Cahiers de Civilisation Médiévale 56 (2013): 3-38.

1335 Klein, Peter. "Rupert de Deutz et son commentaire illustré de l'Apocalypse à Heiligenkreuz." Journal des Savants 1, no. 1 (1980): 119-40.

Klein, Peter. "Im Spannungsfeld von Endzeitängsten. Konflikten mit dem Islam und liturgischer Praxis: Die Erneuerung der Beatus-Illustration im 10. Jahrhundert.” In Im Schnittpunkt der Kulturen/ Cruce de Culturas. Architektur und ihre Ausstattung auf der Iberischen Halbinsel im 6.-10/11. Jahrhundert. Arquitectura y su decoración en la Península Ibérica del siglo VI al X/

$1340 X I$, ed. Ines Käflein, Jochen Staebel and Matthias Untermann, 11-48. Frankfurt: Vervuert

AQ11 Verlag - Madrid: Iberoamericana, 2016 (forthcoming).

Lackner, Bede K. “The Liturgy of Early Citeaux.” In Studies in Medieval Cistercian History 13. Presented to Jeremiah F. O'Sullivan, ed. M. Basil Pennington, 1-34. Spencer: Cistercian Publications, 1971.

Lekai, Louis J. The Cistercians. Ideals and Reality. Kent, OH: The Kent State University Press, 1977.

1345 Machado, Ana María. "Memory, Identity and Women's Representations in the Portuguese Reception of Vitae Patrum: Winning a Name." In Reading Memory and Identity in the Texts of Medieval European Holy Women, ed. Margaret Cotter-Lynch and Brad Herzog, 135-64. New York: Palgrave Macmillan, 2012.

Marques, Maria Alegria. Estudos sobre a Ordem de Cister em Portugal. Lisboa: Coimbra, Edições Colibri/ Faculdade de Letras da Universidade de Coimbra, 1998.

1350 Marques, Maria Alegria. “A Introdução da Ordem de Cister em Portugal.” In La Introducción del Císter en España y Portugal, 165-93. Burgos: La Olmeda, 1991. 
Marques, Maria Alegria. "O mosteiro de Lorvão: ainda a saída dos monges e a entrada das freiras." Revista de História da Sociedade e da Cultura 11 (2011): 57-74.

Melo, Maria João, Rita Araújo, Rita Castro and Conceição Casanova. "Colour degradation in medieval manuscripts." Microchemical Journal 124 (2016): 837-44.

Melo, Maria João, Rita Castro and Maria A. Miranda. "Colour in Medieval Portuguese Manuscripts: Between Beauty and Meaning." In Science and Art: The Painted Surface, eds. A. Sgamellotti, B.G. Brunetti, C. Miliani, 170-92. London: Royal Society of Chemistry, 2014.

Melo, Maria João, Maria A. Miranda, Catarina Miguel, Ana Lemos, Ana Claro, Rita Castro, Vânia S.F. Muralha, João A. Lopes and António P. Gonçalves. “The Colour of Medieval Portuguese Illumination: An Interdisciplinary Approach.” Medieval Colours: Between Beauty and Meaning. Revista de História da Arte, ed. Maria A. Miranda, Maria J. Melo and Mark Clarke, no. 1, Série W (2011): 147-69.

Melo, Maria João, and Maria A. Miranda. “Colour in Romanesque Manuscripts.” In Inside Illuminations: Art Technical Research \& the Illuminated Manuscript, ed. L. Watteeuw, M. van

AQ12 Bos and A. Dubois. Leuven: Peeters (forthcoming).

Miguel, Catarina, Ana Claro, António P. Gonçalves, Vânia S. F. Muralha and Maria João Melo. "A study on red lead degradation in a medieval manuscript Lorvão Apocalypse (1189)." Journal of Raman Spectroscopy 40 (2009): 1966-73.

Millares Carlo, Agustín. "Problemas que suscita la escritura de los 'Beatos'." In Actas del Simposio para el estudio de los códices del "Comentario al Apocalipsis" de Beato de de Liébana, vol. 1, 193202. Madrid: Joyas Bibliográficas, 1978.

Miranda, Maria A. "A construção de uma imagem de poder. A figura do rei no $<$ ARBOR consanguinitatis>”. In Imágenes del poder en la Edad Media. Estudios de homenaje a Fernando Galván Freile, vol. 2, 341-54. León: Servicio de Publicaciones, 2011.

Miranda, Maria A. "Iluminura românica em Portugal.” In La miniatura medieval en la Península Ibérica, ed. Joaquín Yarza Luaces, 375-418. Murcia: Nausícaä, 2007.

Miranda, Maria A., and Maria João Melo. "Secrets et découvertes, en couleur, dans les manuscrits enluminés.” In Portuguese Studies on Medieval Illuminated Manuscripts, ed. Maria A. Miranda and Alicia Miguélez Cavero, 1-30. Barcelona: Brepols, 2014.

1375 Morales, Ambrosio. Viage a los reynos de España. Madrid: Antonio Marín, 1765

Mundó, Anscari. “Sobre los códices de Beato." In Actas del Simposio para el estudio de los códices del "Comentario al Apocalipsis" de Beato de de Liébana, vol. 1, 109-16. Madrid: Joyas Bibliográficas, 1978.

Mundó, Anscari, and Manuel Sánchez Mariana. El Comentario de Beato al Apocalipsis. Catálogo de los Códices. Madrid: Biblioteca Nacional, 1976.

1380 Muralha, Vânia S.F., Catarina Miguel and Maria João Melo, "Micro-Raman study of Medieval Cistercian 12-13th century manuscripts: Santa Maria de Alcobaça, Portugal.” Journal of Raman Spectroscopy 43 (2012): 1737-46.

Nascimento, Aires A. "A experiência do livro no primitivo meio alcobacense." In IX Centenário do Nascimento de S. Bernardo. Encontros de Alcobaça e Simpósio de Lisboa. Actas, 121-45. Braga: Universidade Católica Portuguesa e Câmara Municipal de Alcobaça, 1991.

1385 Nascimento, Aires A. "Livros e tradições hispânicas no mosteiro cisterciense de Arouca." In Escritos dedicados a José María Fernández Catón, ed. Manuel C. Díaz y Díaz, Mercedes Díaz de Bustamante, and Manuela Domínguez García, vol. 2, 1041-58. León: Centro de Estudios e Investigación San Isidoro, 2004.

Nascimento, Aires A. “Um Marial Alcobacense.” Didaskalia 9, no. 2 (1979): 339-412.

Nascimento, Aires A. "Le scriptorium d'Alcobaça: identité et corrélations.” Lusitania Sacra 2 Série,

4 (1992): 149-62.
Nascimento, Aires A. "Tempos e livros medievos: os antigos códices de Lorvão. Do esquecimento à recuperação das tradições.” In Ler contra o tempo. Condições dos textos na cultura portuguesa, vol. 1, 389-410. Lisboa: Centro de Estudos Clássicos, 2012.

Nascimento, Aires A. “Um testemunho da tradição hispânica dos 'Moralia in Job': Lisboa, BN, Alc. 349 - subsídios para o seu enquadramento.” Arquivos Leoneses 78-80 (1986): 313-31.

1395 Nascimento, Aires A., and António Dias Diogo. A encadernação Portuguesa medieval: Alcobaça. Lisbon: Imprensa Nacional - Casa da Moeda, 1984. 
Neuss, Wilhem. Die Apokalypse des Hl. Johannes in der altspanischen und altchristlichen BibelIllustration. Münster: Verlag der Aschendorffschen Verlagsbuchhandlung, 1931.

Ó Riain, Diarmuid. "The Magnum Legendarium Austriacum: a new investigation of one of the medieval Europe's richest hagiographical collections." Analecta Bollandiana 122 (2015): 87-165.

Oliver, Judith. Singing with Angels: Liturgy, Music and Art in the Gradual of Gisele von Kerssenbock. Turnhout: Brepols, 2007.

Raizman, David. "Prayer, Patronage, and Piety at Las Huelgas: New Observations on the Later Morgan Beatus (M. 429)." In Church, State, Vellum, and Stone: Essays on Medieval Spain in Honor of John Williams, ed. Therese Martin and Julie A. Harris, 236-73. Leiden: Brill, 2005.

Reynolds, Roger. "Apocalypses New: The Recently Discovered Beneventan Illustrated Beatus in Geneva in its South Italian Context." Peregrinations: Journal of Medieval Art and Architecture 3, no. 4 (2012): 1-44.

Rodrigues, Jorge. Mosteiro de Alcobaça. Lisboa: Ministério de Cultura / IPPAR, Edições Scala, 2007. Romero-Pose, Eugenio. "The Beatus Commentary on the Apocalypse." In El Beato de Osma. Estudios, 53-104. Valencia: Vicent García Editores, 1992.

1410 São Boaventura, Fortunato de. Historia chronologica, e critica da Real Abbadia de Alcobaça. Lisboa: Impressão Regia, 1827.

Shailor, Barbara. "The Beatus Manuscript of Burgo de Osma: A Paleographical and Codicological Study.” In El Beato de Osma. Estudios, 29-52. Valencia: Vicent García Editores, 1992.

Suárez González, Ana I. "El Beato del Archivo Histórico Provincial de Zamora." Hispania Sacra 55 (2003): 434-77.

Suárez González, Ana I., "Cistercian Scriptoria in the Twelfth and Thirteenth Centuries: A Starting Point." In Culture and Society in Medieval Galicia: A Cultural Crossroads at the Edge of Europe, ed. James D’Emilio, 765-811. Leiden: Brill, 2015.

Suárez González, Ana I. Fragmentos de libros, bibliotecas de fragmentos. Zamora: Instituto de Estudios Zamoranos "Florián de Ocampo", 2003.

Suárez González, Ana I. "El libro en los claustros cistercienses (una aproximación c.1140-1240).” In El Monacato en los reinos de León y Castilla (Siglos VII-XIII). X Congreso de Estudios Medievales 2005, 163-325. León: Fundación Sánchez-Albornoz, 2007.

Suárez González, Ana I. "Los otros beatos." In Suárez González, Ana, and John Williams, Fragmentos de Beatos, 5-100. Madrid: Testimonio, 2009.

Szirmai, Janos A. The Archaeology of Medieval Bookbinding. Aldershot: Ashgate, 1999.

Untermann, Matthias. Forma Ordinis. Die mittelalterliche Baukunst der Zisterzienser. München: Deutscher Kunstyerlag (Kunstwissenschaftliche Studien, 89), 2001.

Vega Casado, Juan A. "El monasterio de San Martín de Castañeda. De mozárabe a cisterciense." In Actas del III Congreso Internacional sobre el Cister en Galicia y Portugal, vol. 1, 479-99. Ourense: Grupo Francisco de Moure, 2006.

Vernet, André. La bibliothèque de l'abbaye de Clairvaux du XIIe au XVIIIe siècle. Vol. I Catalogues et répertoires. Paris: CNRS Éditions, 1979.

1430 Vivancos, Miguel C. "El Beato de San Andrés de Arroyo." In Beato de Liébana. Códice del Monasterio Cisterciense de San Andrés de Arroyo, vol. 2, 15-70. Barcelona: Moleiro, 1998.

Voelke, William, Peter Klein, David Raizman et al. Estudio del Manuscrito del Beato de Las Huelgas M. 429. Valencia, Scriptorium S.A., 2005.

Waddell, Chrysogonus. Twelfth-Century Statutes from the Cistercian General Chapter. Latin Text with English Notes and Commentary. Cîteaux: Commentarii Cisterciensis, 2002.

1435 Walker, Rose. Views of Transition. Liturgy and Illumination in Medieval Spain. London: British Library, 1998.

Williams, John. "The Illustrations of the Beatus of Burgo de Osma." In Burgo de Osma. Estudios, 105-44. Valencia: Vicent García Editores, 1992.

Williams, John. The Illustrated Beatus. A Corpus of the Illustrations of the Commentary on the Apocalipse, vol. 1. Introduction. London: Harvey Miller, 1994.

1440 Williams, John. The Illustrated Beatus. A Corpus of the Illustrations of the Commentary on the Apocalypse, vol. 5: The twelfth and thirteenth centuries. London: Harvey Miller, 2003. 
Williams, John. A Spanish Apocalypse. The Morgan Beatus Manuscript. New York: George Braziller, 1975.

Williams, John. Visions of the End in Medieval Spain. Catalogue of Illustrated Beatus Commentaries on the Apocalypse and Study of the Geneva Beatus, ed. Therese Martin. Amsterdam: Amsterdam University Press, 2016.

1445 Yarza Luaces, Joaquín. "Manuscritos iluminados en el Císter.” In Monjes y monasterios. El Císter en el medievo de Castilla y León, 399-409. Valladolid: Junta de Castilla y León, 1998.

\section{Appendix: Modus Operandi, Equipment description and acquisition conditions}

After examining the illuminations of the Alcobaça Beatus with the naked eye and under the microscope, we began our journey into the invisible, using advanced analytical techniques to explore the molecular universe of these manuscripts. Given the complexity and value of these materials, we usually interface the analytical techniques with a microscope. This enables us to study very small areas, typically on a micrometre scale, with a micro $(\mu)$ one thousand times smaller than a milli (as in millimetre). But the molecules we needed to characterize are much smaller, and can only be "seen" at the nano-level-a nanometre being one thousand times smaller than a micrometre. However, these molecules can nevertheless be detected through spectroscopic signals, known as spectrum. ${ }^{88}$

Our analysis combined elemental with spectroscopic techniques. By detecting the elements present in the pigments, micro X-ray fluorescence (microXRF) allows us to identify the colourants and, in certain cases, it enables the semi-quantification of pigment mixtures (by comparison with reference materials). Spectroscopic techniques deliver a spectrum, a simulacrum of the real molecular world; this complex image is interpreted by comparison with reference databases and by decoding the signal obtained as much as possible.

Raman microscopy (microRaman), Fourier Transform Infrared spectroscopy (microFTIR), emission fluorescence spectroscopy (microspectrofluorimetry), and Fibre Optic Reflectance Spectroscopy (FORS) in the UV-Visible region are powerful complementary spectroscopic techniques for the characterization of colourants in medieval manuscripts. Raman and infrared spectroscopy reveal a "molecular fingerprint": if a single compound is present, it is possible with these techniques to unequivocally characterize it. Complexity arises because we are usually faced with aged, superimposed mixtures of compounds. Another layer of difficulty is added when a compound is not present in our reference database.

The creation of this database of colourants, binders, and colour paints was paramount to our studies of illuminations. These standards were determined by our own analyses of medieval paint and were produced following and adapting the procedures described in contemporary written sources such as recipe books and medieval technical treatises.

During an on-site investigation, the first screening involves FORS and microXRF, the latter of which indicates the possible colourants and extenders present, and allows for the initial quantification of these elements; moreover, the $70 \mu \mathrm{m}$ offered by the microXRF enables us to obtain data on the distribution of a certain paint colour throughout the manuscript.

MicroRaman allows for high spatial resolution (1-5 $\mu \mathrm{m}$ spot) so that diverse paint components may be analysed separately. In addition to the spectroscopic investigation, paints are also analysed by optical microscopy, which allows us to understand how the final colour is built up, to detect possible degradation phenomena, and to sample the colour paints that will be subjected to a more detailed characterization in the laboratory in what concerns the colourants, binders, and additives. In the laboratory, a sample will typically first be analysed by microFTIR, allowing us to characterize binders and gain insight into the full paint formulation. If a dye is present, microspectrofluorimetry may be carried out first, as it requires no contact with the colour paint and employs a low-intensity radiation. Surface Enhanced Raman Spectroscopy (SERS) will be utilized for at least

\footnotetext{
${ }^{88}$ For more information on our methodology, see Melo and Miranda, "Colour in Romanesque manuscripts" (forthcoming).
} 
one micro-sample to determine the molecular fingerprint of the dye. Depending on degradation phenomena or other challenging aspects, other analytical techniques may also be selected.

Colour mapping. The regions occupied by colours were mapped using an in-house- built MATLAB function (MATLAB 7.11.0 R2010b). The steps involved in the mapping are briefly described as follows: after loading a digital image of the illumination without the parchment background into the MATLAB workspace (in RGB format), it is automatically calibrated into a pure colour palette (one consistent with the exact colours used in Romanesque illuminations). The image is then converted to CIELAB format (3D data). After the chromatic optimization step of the illuminations, each pixel of the image is analysed and assigned to the closest pure colour. The pixels are then replaced by the "pure colour" assigned to them. The pixels corresponding to a given colour are calculated in percentages, which can then be converted to area $\left(\mathrm{cm}^{2}\right)$.

On-site investigations. The molecular analysis of the Alcobaça Beatus was carried out in June 2015 at the Biblioteca Nacional de Portugal (BNP). A total of eighteen folios were analysed in situ by micro XRF and FORS: folios $1,5 \mathrm{v}, 8,10,10 \mathrm{v}, 12,12 \mathrm{v}, 13 \mathrm{v}, 15 \mathrm{v}, 16,18,18 \mathrm{v}, 21 \mathrm{v}, 31,47 \mathrm{v}$, $144,144 \mathrm{v}$, and 183. The binding and endleaves were also analysed in situ by microXRF. Microsampling of the manuscript was performed with a micro-chisel under a Leica KL 1500 LCD microscope equipped with a $12 \mathrm{x}$ objective lens, and a Leica Digilux digital camera with external illumination via optical fibres. Eighteen micro-samples were selected for laboratory analysis.

Micro-EDXRF results were obtained using an ArtTAX spectrometer of Intax GmbH, with a low-power molybdenum (Mo) X-Ray tube attaining a microspot with a spatial resolution of circa $70 \mu \mathrm{m}$, an X-flash detector refrigerated by the Peltier effect (Sidrift), sustained by a mobile arm (providing a major freedom in choosing the spot of analysis). The accuracy of the incident beam position on the sample is achieved through three beams crossing diodes controlled by an integrated CCD camera; the characteristic X-rays emitted by the sample (at $40^{\circ}$ ) are detected by a silicon drift electro-thermally cooled detector with a resolution of $160 \mathrm{eV}$ at $\mathrm{Mn}-\mathrm{Ka}$. This apparatus allows for a simultaneous multi-element analysis in the element range from $\mathrm{Mg}$ (magnesium, atomic number 12) to $U$ (uranium, atomic number 92).

The experimental parameters used were: $40 \mathrm{kV}$ of voltage, $300 \mu \mathrm{A}$ of intensity, for $120 \mathrm{~s}$, under Helium gas flux. $\mathrm{Si}, \mathrm{Mn}, \mathrm{Cu}$, and $\mathrm{Pb}$ standards were used as calibration standards in the beginning and at the end of the each day of data acquisition.

Reflectance spectra were obtained with a reflectance spectrophotometer Ocean Optics in the UV-Vis region through optical fibres. The measurements were conducted over an acetate sheet with a hole and an oring on top of it. The fibre was then positioned on top of the oring at $90^{\circ}$ angle, slightly touching. Through this method, we tried to minimize the direct contact of the support of the fibres, in order to protect the illuminations. The analyses were obtained with 8 ms integration time and 15 scans.

Raman microscopy was carried out using a Labram 300 Jobin Yvon spectrometer, equipped with a He-Ne laser of $17 \mathrm{~mW}$ power operating at $632.8 \mathrm{~nm}$ (red laser), and a $532 \mathrm{~nm}$ diode laser of $50 \mathrm{~mW}$ power operating at $75 \%$ (green laser). Spectra were recorded as an extended scan. The laser beam was focused either with a $50 \times$ or a $100 \times$ Olympus objective lens. The laser power at the surface of the samples was between 4.3 and $0.17 \mathrm{~mW}$.

Infrared analyses were performed using a Nicolet Nexus spectrophotometer coupled to a Continu $\mathrm{m}$ microscope ( $15 \mathrm{x}$ objective) with a MCT-A detector cooled by liquid nitrogen. The spectra were collected in transmission mode, in $50-\mu \mathrm{m}$ areas resolution setting $4 \mathrm{~cm}^{-1}$ and 128 scans, using a Thermo diamond anvil compression cell. For some infrared spectra, the system was purged with nitrogen prior to the data acquisition; for all infrared spectra, the $\mathrm{CO}_{2}$ absorption at circa 2400-2300 $\mathrm{cm}-1$ was removed from the acquired spectra $\left(4000-650 \mathrm{~cm}^{-1}\right)$. To improve result robustness, more than one spectrum was acquired from different sample spots.

Fluorescence excitation and emission spectra were recorded with a Jobin Yvon/Horiba SPEX Fluorog 3-2.2 spectrofluorometer. Fluorescence spectra were corrected for the wavelength response of the system. For microspectrofluorimetry analyses, the latter equipment was hyphenated to an Olympus BX51 M confocal microscope, with spatial resolution controlled with a multiple-pinhole turret, corresponding to a minimum $2 \mu \mathrm{m}$ and maximum $60 \mu \mathrm{m}$ spot, with 50x objective. Standard dichroic filters of 500 and $600 \mathrm{~nm}$ were used at $45^{\circ}$ to collect the emission and excitation spectra, 
respectively. Emission spectra were acquired exciting at $490 \mathrm{~nm}$ and excitation spectra were recorded by collecting the signal at $610 \mathrm{~nm}$. Both types of spectra were acquired on a $30-\mu \mathrm{m}$ spot (pinhole 8 ) and the following slits set: emission slits $=3 / 3 / 3 \mathrm{~mm}$, and excitation slits $=5 / 3 / 0.8 \mathrm{~mm}$. The optimization of the signal was performed for all pinhole apertures through mirror alignment in the optic pathway of the microscope, following the manufacturer's instructions. Spectra were collected after focusing on the sample (eye view) followed by signal intensity optimization (detector reading). Emission and excitation spectra were acquired on the same spot whenever possible. The paint reconstructions were mainly analyzed in situ, while the historical samples were analyzed in micro-samples. Five spots per sample were measured to ensure reproducibility of the results. 